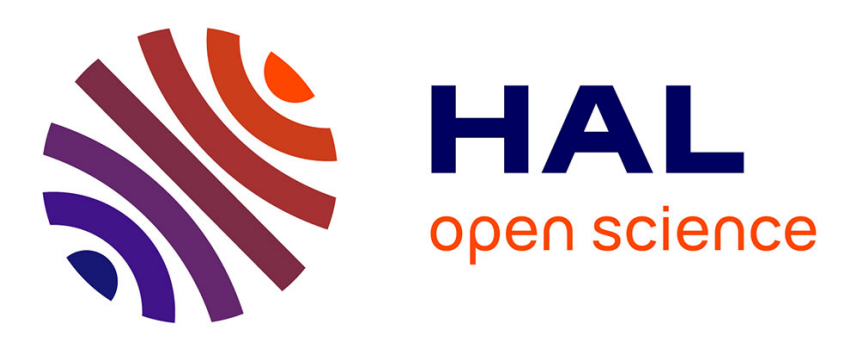

\title{
Kaolinite dating from Acrisol and Ferralsol: A new key to understanding the landscape evolution in NW Amazonia (Brazil)
}

Maximilien Mathian, Guilherme Taitson Bueno, Etienne Balan, Emmanuel Fritsch, Nádia Regina Do Nascimento, Madeleine Selo, Thierry Allard

\section{To cite this version:}

Maximilien Mathian, Guilherme Taitson Bueno, Etienne Balan, Emmanuel Fritsch, Nádia Regina Do Nascimento, et al.. Kaolinite dating from Acrisol and Ferralsol: A new key to understanding the landscape evolution in NW Amazonia (Brazil). Geoderma, 2020, 370, pp.114354. 10.1016/j.geoderma.2020.114354 . hal-03047287

\section{HAL Id: hal-03047287 https://hal.science/hal-03047287}

Submitted on 14 Dec 2020

HAL is a multi-disciplinary open access archive for the deposit and dissemination of scientific research documents, whether they are published or not. The documents may come from teaching and research institutions in France or abroad, or from public or private research centers.
L'archive ouverte pluridisciplinaire HAL, est destinée au dépôt et à la diffusion de documents scientifiques de niveau recherche, publiés ou non, émanant des établissements d'enseignement et de recherche français ou étrangers, des laboratoires publics ou privés. 


\section{Kaolinite dating from Acrisol and Ferralsol: a new key to understanding the landscape evolution in NW Amazonia (Brazil)}

Maximilien Mathian ${ }^{1}$, Guilherme Taitson Bueno ${ }^{2}$, Etienne Balan ${ }^{1}$, Emmanuel Fritsch ${ }^{1}$, Nádia Regina do Nascimento ${ }^{3}$, Madeleine Selo ${ }^{1}$, Thierry Allard ${ }^{1}$

${ }^{1}$ Sorbonne Université, Institut de minéralogie, de physique des matériaux et de cosmochimie, UMR CNRS 7590, IRD, MNHN, Université Pierre et Marie Curie, 4 Place Jussieu, 75005, France

${ }^{2}$ Federal University of Goiás - UFG, Instituto de Estudos Socioambientais, Av. Esperança, s/n Samambaia, Goiânia - GO, 74001-970, Brazil

${ }^{3}$ University of the State of São Paulo - UNESP Instituto de Geociências e Ciências Exatas, Rua 10, 2527, Rio Claro - SP, 13500-230, Brazil.

Abstract:

Ferralsols and Acrisols are major types of soils of the Amazon basin observed on various landform units comprising plateau surfaces, incised hills at their edges and slopes. The present study focuses on an Acrisol developed on plateaus surfaces from northwest Amazonia and a Ferralsol from the convex hills of the incised plateau edges. Local geomorphologic models of weathering covers suggest that Ferralsols are younger than plateau Acrisols but the absolute chronology of their formation is still lacking. This type of information is however critical to understand the evolution of northwest Amazon Basin landscapes and to identify its link with major climatic and geomorphologic events. In this paper, kaolinite-rich samples from soils and saprolites belonging to a transect in the São Gabriel da Cachoeira region (Amazon state, Brasil) are investigated. Based on their crystal-chemical characters, several types of kaolinites are identified. Using a previously developed methodology based on electron paramagnetic resonance (EPR) spectroscopy, crystallization ages are proposed for these different kaolinites. Saprolite kaolinites are dated from 6 to $3.6 \mathrm{Ma}$ in the Acrisol profile and display significantly more recent ages $(<1 \mathrm{Ma})$ in the Ferralsol saprolite. Kaolinite from solum (soils horizons above the $\mathrm{C}$ horizon) display ages ranging from 2.5 to $1 \mathrm{Ma}$ for both the Acrisol and Ferralsol. Three distinct weathering stages are thus unraveled by kaolinite dating. The Acrisol saprolite displays the older weathering stage preserved in the investigated soil sequence. It is followed by a single weathering stage leading to the formation of both soils. These two stages can be correlated to the formation of two paleosurfaces recognized at the scale of the South America subcontinent as the Miocene Vehlas and the Quaternary Paraguaçu surfaces, indicating that the Curicuriari profiles evolved during periods favorable to tropical weathering surfaces development in Amazonia. The last weathering stage corresponds to the saprolite formation in the Ferralsol profile, which is still developing under the present Amazonian climate. This still active, late 
weathering stage is tentatively related to the more significant drainage and relief dissection occurring on the plateau edges.

Keywords: Laterite, EPR dating, Kaolinite, Ferralsol/Acrisol transition, Amazonia

\section{Introduction}

Tropical weathering covers extend over one third of the present-day continental surfaces (Nahon, 2003) and develop over a large variety of climates, geological units and elevations. They generally consist in indurated or unconsolidated regoliths with a mineralogy dominated by various oxides/hydroxides/oxyhydroxides (iron, aluminium), kaolinite and quartz. During the last 20 years, several methods have been developed to date secondary minerals (i.e. minerals formed due to weathering), such as Ar/Ar dating of Mn oxides (Vasconcelos, 2015 and reference therein), (U-Th)/He dating of iron oxides or oxyhydroxides (Shuster et al., 2005) and electron paramagnetic resonance (EPR) dating of kaolinites (Balan et al., 2005). They demonstrated that these minerals can be relics of intense weathering pulses that can be associated to specific paleoclimatic conditions (Vasconcelos et al., 1999 and ref. therein; Balan et al., 2005; Beauvais et al., 2008; Retallack et al., 2010; Bonnet et al., 2016; Allard et al., 2018). However, a potential tectonic/eustatic control leading to water table falling and impacting on the regolith development cannot be excluded, as suggested by Linton (1955), Ollier (1988), Bland and Rolls (1998) and Taylor and Howard (1999). By deciphering past preferential periods of weathering and documenting the expected links with these two classes of processes, i.e., drainage and watertable migration, dating of secondary minerals improves our understanding of regolith genesis and more generally of the evolution of continental surfaces through geological time.

Among tropical weathering regions, the Amazon basin has been widely studied due to its large size (about 7 millions $\mathrm{km}^{2}$, Taitson Bueno et al., 2019), major input of water and sediments to the oceans (Gaillardet, 1997) and diversity of regoliths (Richter and Babbar, 1991). The Brazilian project of natural resources mapping (Radam, 1972-1978) highlighted the presence of four main types of soils in Amazonia: Ferralsols (rich in sesquioxides), Acrisols (cations desaturated and displaying a clayey accumulation horizon at depth), groundwater laterite/gleysols systems and giant watterlogged Podzols. Acrisols and Ferralsols are often referred to as lateritic soils in the broad sense. We consider herein that the solum corresponds 
to the horizons above the saprolite ( $\mathrm{C}$ horizon) in a soil profile. In the upper Amazon basin, transitions between Ferralsols, Acrisols and Podzols are observed (Radam, 1972-1978; Lucas et al., 1987; Almeida et al., 2005; Fritsch et al., 2011). These soils are developed on various primary rocks, from Amazonian sediments to granitoïd rocks of the Guyana Shield or related intrusions. An understanding of their genesis and interlink would be an important step in the reconstruction of the evolution of the Amazon Basin landscape through space and time.

In the central Amazon Basin (Manaus region), Ferralsols developed at the expense of sedimentary formation rich in kaolinite such as, e.g., the Alter do Chao formation (Lucas et al., 1996; Montes et al., 2002; Balan et al., 2005). The kaolinites from these profiles are increasingly disordered from bottom to top (Lucas et al., 1987; Balan et al., 2007). The dating of these clay minerals leads to ages older than $25 \mathrm{Ma}$ for the sedimentary horizons, indicating extensive formation or transformation of kaolinite posterior to the late cretaceous deposition of the sediments, and within 11 to $6 \mathrm{Ma}$ for the soil horizons (Balan et al., 2005). These younger Miocene ages were interpreted as reflecting kaolinite dissolution and recrystallization under the action of supergene weathering fronts in the regolith.

The Ferralsol/Podzol (Lucas et al., 1996; Dubroeucq et Volkoff, 1998; Do Nascimento et al., 2004; Ishida et al., 2014) or red to yellow Ferralsols transitions (Fritsch et al., 2005; Balan et al., 2007) have been studied in the Amazon basin. The "yellowing process" of Ferralsols proceeds with the progressive replacement of kaolinite, hematite and Al-poor goethite by Alrich goethite and gibbsite presumably resulting from the action of the present-day humid climate (Fritsch et al., 2002; 2005). Yellowing of red Ferralsols, linked to mineralogical transformations and changes in soil structure, was also described in other parts of the world, such as Africa (Maignien, 1961; Chauvel et Pedro, 1978; Fritsch et al., 1989); it is mainly related to the influence of climate and topography.

Acrisols and Ferralsols occupy a large part of the Amazonian landscape (Figure 1 A), however the transition between them is still poorly understood. In large parts of the basin, Acrisols occur mostly along the slopes of the incised plateaus, whereas the Ferralsols occur on the well drained flat top surfaces of these plateaus. A related general model of evolution of weathering covers through various stages of degradation as a function of topography and involving successive processes such as hydromorphy and clay translocation was proposed (see Melfi et al., 1996). This model describes a common sequence Ferralsols - Acrisols - Podzols 
that is commonly encountered in the field through the Amazon bassin. However, in the northwestern part of the basin, where this study takes place, Ferralsols are specifically developed on the plateaus incised edges, whereas Acrisols occur on the plateau centres surrounding podzolized waterlogged areas. A comprehensive regional model of geomorphological and pedological evolution was proposed by Taitson Bueno (2009) to account for this particular distribution, where Acrisols are older than Ferralsols. However, no absolute dating was yet performed to sustain this model and to understand the transition between the involved weathering covers as a function of past orogenenic or paleoclimatic forcing.

In the present study, one yellow Acrisol and one red Ferralsol profile, including their respective saprolites, from one transect in the Sao Gabriel region (Rio Curicuriari watershed, Brazil, NW Amazon Basin) were investigated. A special attention was paid to kaolinite dating using the EPR dating methodology described in Balan et al. (2005). In unconsolidated tropical soils, it is proposed that kaolinites form and recrystallize in large amount during intense precipitation periods (Mathian et al., 2018) that can be related to known paleoclimatic/geodynamic events. This study provides the chronology of the local development of weathering profils, investigates their potential relationship and then specifies the regional model of geomorphological and pedological evolution.

\section{Location and description of soil profiles}

\subsection{Regional settings}

The study area is located in NW Amazonia (Brazil) on the K'Mudku Shear Belt formation in the south of the Guyana shield (Santos et al., 2000). The present-day climate is described as a monsoonal climate (i.e. with contrasting seasonal precipitations). The average temperature is $26.4^{\circ} \mathrm{C}$, the mean annual air humidity set around $84 \%$ and the mean annual rainfalls are about $2900 \mathrm{~mm}$ per year.

The northern part of the Amazon basin displays transitions between three of the characteristic soils of Amazonia: Ferralsols, Acrisols and seasonally waterlogged Podzols, as reported in Fig. 1A (Radam, 1972-1978; Lucas et al., 1987; Almeida et al., 2005; Fritsch et al., 2011, Taitson Bueno et al., 2019). The studied soil sequence is located in the Rio Curicuriari area (Fig. 1), in the south of the Rio Negro basin near to the city of Sao Gabriel da Cachoeira (northwest of Brazil). The topography of the region is fully described in Dubroeucq and Volkoff 
141 (1988) and Allard et al. (2018). It consists in a succession of low elevation plateaus (about 80 $142 \mathrm{~m}$ of altitude) incised by streams and rivers (Supporting Information (SI) 1). The regional 143 basement is dominated by mylonite rocks dated ca 1.20 Ga (Santos et al., 2000). However the 144 studied soils are developed on intrusive "Uaupés" granitoïds, dated around 1.51 Ga and 145 preserved during the Shear Belt activation (Almeida, 2005). The Uaupés granitic enclaves are 146 mainly composed of monzogranite, a rock with a mineralogy dominated by feldspars, biotite, 147 titanite, amphibole, quartz, apatite and few accessory minerals as magnetite, ilmenite, and pyrite 148 (Dall'agnol and Macambira, 1992; Santos et al., 2000 and Almeida, 2005).

149

150

151

152

153

154

155

156

157

158

159

160

161

162

163

164

165

166

167

168

169

170

171

172

173

174

The western part of the Curicuriari basin is dominantly covered by Podzols, whereas the central eastern part of this area is mainly covered by Ferralsols and Acrisols (Fig. 1B). Several "pouches" of Podzols can be found in the dominant Acrisol zone of this region. Seldom, direct contact between Ferralsols and Podzols can also be observed (Fig. 1B). At the regional scale, the typical soil sequence on the flat plateau surface is Ferralsol-Acrisol-Podzol, from the plateau edges to its center. The nature of soils is strongly linked to the topographical units in the landscape. The Podzols formed over inundated plains and depressions, Acrisols on poorly drained plateau surfaces and Ferralsols on the better drained dissected plateau edges. Similar relations of soil types with the topography and hydrologic parameters have also been reported in studies of other regoliths developed in Amazon region (Fritsch et al., 2011 and ref. therein). In these previous studies, Podzols evolved at the expense of Acrisols and Acrisols at the expense of Ferralsols, both transformations progressing from the center to the edges of plateaus at a regional scale and upwards along the slopes at a local scale (Melfi et al., 1996). Indeed, the dissection of plateau edges by stream incision enhanced drainage efficiency and eroded part of the former plateau soils. On the flat or convex tops of residual hills the Ferralsols remained, while along the new slopes a new generation of soils as Cambisols and Acrisols developed.

In contrast, the soil distribution in the Curicuriari region, with Ferralsol developed over incised plateau edges and Acrisol on flat plateaus, raises questions about the lateral progression of Ferralsols at the expense of the local Acrisols (Fig. 1C). On the other hand, Acrisols may result from the complete transformation of older Ferralsols on the plateaus. Kaolinite dating in the weathering covers should allow us to bring more decisive answers to these issues.

\subsection{Paleoclimates and geodynamic history of the Amazon basin}


The present-day climate of Amazon basin is a monsoonal system, driven by the Atlantic moist air circulation and influenced by the Andean Cordillera (Vonhof and Kaandorp, 2010). The Andean Cordillera blocks the present-day Atlantic easterlies to create a northwestern barrier jet called the South-American low-level jet which is critical for the local and continental climate establishment (Insel et al., 2009 and references). Precipitation is blocked on the east side of the Andean Cordillera and thus a precipitation gradient is observed in Amazonia, from the mountains chain to the Atlantic Ocean (Bookhagen and Strecker, 2008; 2010; Taitson Bueno et al., 2019). Using climatic modelling, Insel et al. (2009) also explained that this phenomenon blocked past dry westerlies originated from the Pacific Ocean, although no drastic change of precipitation volume occurred over the Amazon basin due to Andean uplift.

Several studies addressed in detail the evolution of paleoclimate in the Amazon Basin. Unlike other continental surfaces, Brazil has not substantially drifted northward since the Mesozoic. This part of the world has experienced a relatively stable climate, mainly influenced by global climatic variations. Tardy et al. (1991) proposed that a seasonally contrasted warm and humid climate, favourable to tropical weathering surfaces formation (bauxites, iron duricrusts, laterites), affected the Amazonia basin since the late Cretaceous (ca $70 \mathrm{Ma}$ ).

Global paleoclimatic fluctuations should have also affected the Amazon basin. The evolution of ocean temperature is often used as a proxy for global temperature evolution, including continental temperatures. Warmer temperatures can also be linked to higher precipitations on the continent due to a strengthening of oceanic evaporation. Accordingly, warm periods can coincide with peaks of precipitations and temperature in Amazonia. Five main temperature peaks (SI 2) during the Tertiary were reported by Zachos et al. (2001) and confirmed by Cramer et al. (2009): the Palaeocene/Eocene Temperature Maximum (PETM), Early Eocene Climatic Optimum (EECO), Mid-Eocene Climatic Optimum (MECO), Late Oligocene Warming (LOW) and Mid-Miocene Climatic Optimum (MMCO). Present day variations of rainfall intensity between summer and winter are inherited from the migration of the intertropical convergence zone (ITCZ) between the two seasons. Accordingly, factors that influence the ITCZ location, e.g. Milankovitch cycles, also influence the Amazonian climate (Vonhof et Kaandrop, 2010). Accordingly, several authors described an increase of rainfall in South America between 5 and 4 Ma, linked to ITCZ variations (Hovan, 1995 and Billups et al., 1999). 
In addition to the global climatic changes, two major geodynamic events have influenced the Amazon basin climate during the Tertiary (SI 2): the Andean uplift phases (Bookhagen and Strecker, 2008; 2010; Sepulchre et al., 2010) and the closure of the Panama seaway (Sepulchre et al., 2010; Karas et al., 2017). Several uplifts phases have been reported for the Andean orogeny (Hoorn et al., 2010; Campbell et al., 2006, and ref. therein). It begun in the Early Jurassic with an independent development of the northern and central part of the cordillera, which joined during the Miocene. Before that, Pacific westerlies and Atlantic easterlies joined over the Amazon basin, causing more homogeneous precipitations (Sepulchre et al., 2010). The present-day rainfalls gradient was established with the Quechua I uplift phase between 17-15 $\mathrm{Ma}$ and their forcing on air circulation. Accordingly, the Amazonian monsoonal system exists since at least $15 \mathrm{Ma}$ (Vonhof et Kaandrop, 2010 and ref. therein). Three others uplifts events in the last 10 Ma are also reported: the Quechua II uplift (9.5-8.5 Ma) following the Ucayali peneplains event, the Quechua III (ca $6 \mathrm{Ma}$ ) uplift and the last Pliocene uplift event (ca $4 \mathrm{Ma}$ ). Due to their influence on the air mass circulation (Insel et al., 2009), these events potentially caused variations in the local monsoon intensity.

The final closure of the Panama seaway at ca 3.5 Ma (or earlier, see Montes et al., 2015) also influenced the Amazonian climate, affecting the oceanic circulation and Atlantic salinity and temperature. During the Pliocene and Quaternary, the Amazonian climate remained tropical but became drier and colder after the Panama closure according to Rosetti et al. (2005) and ref. therein.

\subsection{Description of soil transect and profiles}

The Caju-Cobra transect (Fig. 1B, Fig. 2, SI 1) of about $1.6 \mathrm{~km}$ long is located in the south of the Curicuriari river (Fig. 2). It is characterized by the presence of the two main soil transitions of the Curicuriari catchment: 1) the lateral transition between the dominant Ferralsol, located along the Rio Curicuriari river, and Acrisol; 2) the lateral transition between Acrisol and waterlogged Podzol. While the second is characterized by a clear limit between the two types of soils, the limit between Ferralsol and Acrisol is less well defined, as it mainly consists in subtle changes in iron oxide nature and clay mineral content. 
243 Cobra transect: one representative of Ferralsol, the Caju profile (CA), and one representative

244 of Acrisol, the Cobra profile (CO2). Both profiles are poorly differentiated, with only six thick horizons detected. These horizons are described in the Table 1.

Both $\mathrm{CA}$ and $\mathrm{CO} 2$ profiles display $\mathrm{A}$ (organic rich), $\mathrm{B}$ (rich in kaolinites and iron oxides/oxy-hydroxides; soil structure) and $\mathrm{BC} / \mathrm{C}$ (soil/saprolite transition) horizons with different colors. According to observations in the field, the Acrisol exhibits a slight clay depletion in surficial horizons. The major horizons have similar thickness in the two profiles, as the A, B and saprolite begin and stop at almost the same depth. In both profiles, the saprolite is $2 \mathrm{~m}$ deep (Table 1). For the present study, twelve samples were collected at similar depths from the $\mathrm{CA}$ and $\mathrm{CO} 2$ profiles (Fig. 2). Note that the primary rocks have not been reached using the auger for both profiles but eroded blocks of a monzogranite were collected in the rivers surrounding the transect.

\section{Material and Methods}

259

All collected samples were sieved at $2 \mathrm{~mm}$ and dried at room temperature. The kaoliniteenriched fractions were obtained after three steps: 1) The removal of residual organic matter using $\mathrm{H}_{2} \mathrm{O}_{2}$; 2) The dissolution of iron oxides/oxyhydroxides using Citrate-DithioniteBicarbonate treatments (Mehra and Jackson, 1960); 3) The collection of the inferior to $2 \mu \mathrm{m}$ grain size fractions of the samples using sedimentation. Magnetic oxides of the Ferralsol samples that would hinder EPR measurement were removed by stirring their infra $2 \mu \mathrm{m}$ fractions in water with a magnet for 24 hours.

X-ray diffraction (XRD) measurements were performed on powders of the bulk $<2 \mathrm{~mm}$ fraction of the samples with a Panalytical Pro MPD equipped with a X'Celerator detector and Co-K $\alpha$ radiations. XRD patterns were recorded with a $2 \theta$ range of 3 to $65^{\circ}$, with steps of $0.017^{\circ}$ and an acquisition time of $480 \mathrm{~ms} / \mathrm{per}$ step.

Chemical analyses were performed at the Service d'Analyse des Roches et Minéraux (SARM, Nancy, France) by inductively coupled plasma atomic optical emission spectrometry (ICP-OES) for major elements quantification and inductively coupled plasma atomic mass 
spectrometry (ICPMS) for the trace elements quantification. The complete procedure and experimental errors are described at http://www.crpg.cnrs-nancy.fr/SARM/index.html.

Uranium mapping in raw samples was performed using ${ }^{235} \mathrm{U}$ induced fission tracks on polished thin sections obtained from resin embedded samples (see part 3.2). Kapton ${ }^{\circledR}$ foils covering the thin sections were used as external detectors (see Price and Walker, 1963 and Kleeman and Lovering, 1967). The samples and standard glasses (SRM- 613 from the National Bureau of Standard, Washington) were irradiated using thermal neutrons at the FRM2 reactor in Munich (Germany). An instant flux of $1.15 .10^{13} \mathrm{n} / \mathrm{cm}^{2} / \mathrm{s}$ was used during $600 \mathrm{~s}$. The revelation of fission tracks, recorded inside the Kapton ${ }^{\circledR}$ foils, was performed by an etching of 8 minutes in an aqueous solution of $14 \% \mathrm{NaClO}$ and $12 \% \mathrm{NaCl}$ heated at $100{ }^{\circ} \mathrm{C}$ (Sélo, 1983). Fission tracks were counted using an optical microscope with an objective of 10x100 magnification in transmitted light.

Kaolinite crystal-chemistry was investigated using Fourier transform mid-infrared spectroscopy (FTIR) and Electron Paramagnetic Resonance spectroscopy (EPR). Transmission FTIR spectra were acquired using solid pellets, made of $1 \mathrm{mg}$ of $<2 \mu \mathrm{m}$ samples and $150 \mathrm{mg}$ of KBr, using a Nicolet Magna 560 FTIR spectrometer. Each spectrum had a resolution of 2 $\mathrm{cm}^{-1}$ in the $400-4000 \mathrm{~cm}^{-1}$ range and was obtained by averaging 100 scans.

EPR spectra were obtained using a Bruker EMXplus ${ }^{\mathrm{TM}}$ spectrometer equipped with a high sensibility cavity at X-Band $(9.86 \mathrm{GHz})$. Acquisitions have been performed with a microwave power of $40 \mathrm{~mW}$, a magnetic field modulation with frequency of $100 \mathrm{kHz}$ and amplitudes from $0.3 \mathrm{mT}$ (Radiation Induced Defects (RID) spectra) to $0.5 \mathrm{mT}$ (total spectra). The EPR signals are characterized by effective $g$ values defined by the resonance condition:

$$
\mathbf{h} v=\mathbf{g B H}
$$

where $\mathrm{h}$ is the Planck constant, $v$ the hyperfrequency, $\beta$ the Bohr magneton and $\mathrm{H}$ the magnetic field. The DPPH standard $(\mathrm{g}=2.0036)$ was used to calibrate the $\mathrm{g}$ values. The powders of infra $2 \mu \mathrm{m}$ samples were measured by this spectrometer in suprasyl grade silica tubes at room temperature. To compare the intensity of each EPR spectra, the spectra were normalized using their height in the tubes, their weight and their recording gain. Reproducibility tests, focused 
on the variation of the spectrometer gain and the samples weight and height, point to a $2 \sigma$ standard error equal to $10 \%$ on the measured RID normalized amplitude.

Dosimetry curves were obtained using artificial irradiations performed on the ARAMIS electrostatic accelerator (Orsay, France). A beam of $1.5 \mathrm{MeV} \mathrm{He}$ ions with a $0.3 \mathrm{~A}$ current was used to simulate radiation effects due to alpha particles on kaolinite structure for six different fluences $\left(310^{11}, 610^{11}, 10^{12}, 310^{12}, 610^{12}\right.$ and $10^{13}$ ions.cm $\left.{ }^{-2}\right)$. The amount of irradiated sample for each fluence was $30 \mathrm{mg}$ (see 3.2 part), which was deposited on circulate steel plate to obtain a thickness of $4 \mu \mathrm{m}$ corresponding to the range of $1.5 \mathrm{MeV} \mathrm{He}^{+}$ions in kaolinite. After irradiation, the unstable defects formed inside the kaolinite structure where annealed by 2 hours heating at $250^{\circ} \mathrm{C}$ (Allard et al., 1994). The A-center content is assessed from the amplitude of the signals of natural or irradiated and annealed samples.

\section{Ferralsol and Acrisol samples characterization}

\subsection{Mineralogy from XRD and FTIR spectroscopy}

The bulk mineralogy of the Ferralsol regolith (CA) is dominated by quartz and gibbsite. In this case, gibbsite appears to be the main product formed in the first stages of the monzogranite weathering (Fig 3B), as also observed in other sites of the Amazon basin (Dubroeucq and Volkoff, 1988; Lucas et al., 1996; Furian et al., 2001). This observation is also consistent with the observation of Shvartsev (2012) which defended that gibbsite is one of the first phases developed during the weathering of Al-rich rocks. In this case, gibbsite precipitation can promote the kaolinite crystallization from the remaining weathering fluids. Other studies confirm this observation, some authors demonstrated the formation of gibbsite during the early stage of granite and gneiss weathering in soils with a high drainage (Herrmann et al., 2007) when other observed that gibbsite is one of the first secondary mineral formed at the expanse of feldspars in the well-drained parts of lateritic saprolites (Anand et al., 1985). In the Ferralsol profile, kaolinite and hematite are also present in all the samples, excepted CA 480. The reddish coloration of these regolith horizons is consistent with the detection of hematite by XRD (Fig. 3B) that can also be linked to the important Fe concentration of the samples (ranging between 4 to $11 \%$, see SI $3 \mathrm{~A}$ ). The presence of hematite indicates a relatively low water activity and a good soil aeration, which is consistent with the free drainage conditions of this profile. A 
noticeable increase of the kaolinite relative content (SI 5) is observed from the saprolite to the soil samples (Fig. 3B), which coincides with a relative decrease in the gibbsite content. With its progressive dissolution from bottom to top, gibbsite acts as an aluminium source participating to kaolinite formation, also supplied by silica released from partial dissolution of quartz and biogeochemical recycling of silica in the topsoil (Lucas et al., 1996). These observations are consistent with the chemical trend (SI 3 and 4), in which the Al/Zr ratio decreases from bottom to top and $\mathrm{Si} / \mathrm{Zr}$ decreases in the profile base but accumulates in the topsoil. The comparison between the evolution of quartz and gibbsite proportion along this profile indicates the relative quartz content increases from saprolite to soil (SI 5). The gibbsite replacement by kaolinite should be faster than the quartz dissolution. The peculiar mineralogy of CA 480 sample may correspond to that of a lower weathering grade of primary rocks. Presence of kaolinite and gibbsite in the clay fraction $(<2 \mu \mathrm{m})$ is confirmed by the FTIR spectra (Fig. 4 D). In all the samples, characteristic $\mathrm{OH}$ stretching bands ascribed to kaolinite and gibbsite are observed (Farmer 1974; Balan et al. 2001; Balan et al. 2006). It is worthy to note that the mineralogical evolution in the Ferralsol profile is different from that related to the yellowing process affecting the Ferralsol (i.e kaolinite, hematite and Al-poor goethite replacement by Al-rich goethite and gibbsite) in the Manaus area as described by Fritsch et al. (2005). The well-drained Ferralsol solum horizons seem more favourable to the kaolinite precipitation than to the goethite and gibbsite formation, despite that the Amazonian climate has been described as favourable to both minerals formation (Fritsch et al., 2011).

The bulk mineralogy of the Acrisol (CO2) profile (Fig. 3A) is different from that of the Ferralsol one. Quartz and kaolinite are the major minerals. The yellow coloration dominantly arises from goethite (Schwertmann, 1993). Goethite is detected as two broad XRD peaks at $4.19 \AA$ and $2.70 \AA$, corresponding to the $\mathrm{d}(101)$, overlapping with the $\mathrm{d}(-1-11)$ peak of the kaolinite, and the $\mathrm{d}(301)$ reflections, respectively. The low intensity of goethite peak attest to its low content consistent with the low Fe concentration of the samples (ranging between 0.9 to $4 \%$, see SI 3B). The presence of goethite indicates a relatively high-water activity and is consistent with the poor drainage conditions expected for the plateau Acrisol. Its proportion seems to decrease in favor of a low hematite content in the 3 top samples of this acrisol profile. Gibbsite is present in the solum, (from CO2 280 to 25), but its content decreases in the topsoil samples (SI 5). The kaolinite/quartz ratio decreases from the saprolite samples to the topsoil. Within the Acrisol solum, the CO2 200 sample displays the highest relative contribution of kaolinite compared to quartz (SI 5). It corresponds to the clay accumulation horizon 
characteristic from Acrisols. As for the Ferralsol, the transition between saprolite and Acrisol solum is well marked. It is characterized by a significant decrease of kaolinite content from the former to the latter. Anatase $\left(\mathrm{TiO}_{2}\right)$ is also present in the samples. The FTIR spectra of the clay fractions (Fig. 4C) indicate that kaolinite is the main phase in this fraction, whereas gibbsite, detected from $\mathrm{CO} 2280$ to the top profile, remains a minor phase.

Additional information about the crystal-chemistry of kaolinite can be inferred from the OH stretching bands (Farmer, 1974; Russel and Fraser, 1994; Balan et al., 2007; 2010). The bands observed at $3698,3670,3650$ and $3620 \mathrm{~cm}^{-1}$ and a high $3670 / 3650 \mathrm{~cm}^{-1}$ intensity ratio characterize well-ordered kaolinites. In addition, the progressive broadening of the 3670 and $3650 \mathrm{~cm}^{-1}$ bands expresses the increase of stacking disorder of kaolinite. The IR spectra of the Ferralsol profile samples (CA, Fig. 4D) are characteristic of disordered kaolinites with a slight order increase toward the top of the profile (except the deepest sample CA 485 which is relatively similar to the CA 240 one). FTIR spectra of Acrisol profile (CO2) kaolinites correspond to well-ordered kaolinites.

The infrared spectra of kaolinite also display a weak signal at $3600 \mathrm{~cm}^{-1}$ which is ascribed to $\mathrm{OH}$ groups bound to $\mathrm{Fe}^{3+}$ ions. It attests for minor substitution of $\mathrm{Fe}^{3+}$ for $\mathrm{Al}^{3+}$ in the kaolinite structure. The signal is more intense in samples of the Acrisol (CO2) profile and increases from saprolite to solum. In the Ferralsol (CA) profile, the signal is very weak and only observed in the most surficial soil samples.

In both profiles, the FTIR signal of kaolinite and gibbsite allows one to clearly distinguish the soils from the corresponding saprolites. In addition, they also demonstrate that the kaolinites from the two profiles have specific crystal-chemical characters such as crystalline disorder and structural iron, indicating that they formed under different conditions. Consequently, these data suggest that the horizons in the Acrisol profile, including the saprolite, cannot be considered as relictual material arising from a ancient Ferralsol. All the analyzed soils and saprolites are distinct units.

\subsection{Electron paramagnetic resonance spectra of clay fractions}

EPR spectroscopy is a sensitive technique enabling the detection of species with unpaired electrons, such as some cations of transition elements or electronic defects (Calas et al., 1988). The EPR spectra of the $<2 \mu \mathrm{m}$ fractions are characteristic of kaolinite (Fig. 4). Two types of 
signal in the $\mathrm{g}=4$ zone can be attributed to structural $\mathrm{Fe}^{3+}$ in kaolinite: the $\mathrm{Fe}^{3+}$ (II) signal, with bands at $\mathrm{g} \sim 4.17$ and 3.69 is ascribed to well-ordered domains whereas the $\mathrm{Fe}^{3+}{ }_{\text {(I) }}$ signal, corresponding to a band near $\mathrm{g}=4.19$, is related to disordered structures such as the one resulting from stacking faults (Gaite et al., 1997; Balan et al., 1999; 2000; 2007). Accordingly, disordered kaolinite is characterized by a relatively intense $\mathrm{Fe}^{3+}{ }_{(\mathrm{I})}$ signal, while a well-ordered one is defined by a dominant $\mathrm{Fe}^{3+}{ }_{\text {(II) }}$ signal. The EPR observations are consistent with FTIR spectroscopy data, the well-ordered kaolinites from the Acrisol profile (CO2) displaying a larger relative contribution of the $\mathrm{Fe}^{3+}$ (II) signal than those from the Ferralsol profile (CA). EPR thus confirms that these profiles contain different types of kaolinites, formed under different geochemical conditions. Based on the EPR signal of structural iron as a probe of structural order, four main types of kaolinite can be distinguished within Ferralsol profile samples. They are referred to as CA1, CA2, CA3 and CA 4, with the CA 4 the most disordered and CA 2 the less disordered type (Table 2). Similarly, four types of kaolinite referred to as C1, C2, C3 and $\mathrm{C} 4$, with $\mathrm{C} 4$ the less disordered and $\mathrm{C} 2$ the most disordered type, can be distinguished in the Acrisol profile (CO2) (Table 3). The corresponding variations of crystalline order are however moderate: 1) kaolinites from the Ferralsol saprolite are slightly more disordered than the one of the soil samples; 2) kaolinites form the Acrisol saprolite are slightly more ordered than the one of the soil samples. These 4 types of kaolinites disorder is the clue that these kaolinites likely formed in different geochemical environment (e.g. Mathian et al., 2019). The Ferralsol (CA) and Acrisols (CO2) profiles do not display a progressive evolution from well-ordered kaolinite at the bottom to strongly disordered one in top soil horizon, as observed in the Manaus region (Lucas et al., 1987; Balan et al., 2007). However, in these profiles, a mixing of kaolinites with different crystalline orders cannot be excluded. In both regoliths, the transition between the soil horizon and the saprolite observed at a macroscopic scale also corresponds to a boundary in terms of kaolinite ordering.

In the $\mathrm{g}=2$ region (Fig. 5), a signal related to trace content of vanadyle $\mathrm{VO}^{2+}(\mathrm{S}=1 / 2)$ molecular ions is also observed. This spectrum has been previously observed in kaolinite and dickite (a kaolinite-group mineral with different stacking order) samples from sedimentary (Muller \& Calas, 1993) or hydrothermal (Mosser et al., 1996) origin. The same spectrum is observed in kaolinite and dickite, exhibiting a hyperfine structure with 8 components (Hall et al., 1980; Gehring et al., 1993).

The vanadyle spectrum is superimposed to the spectrum related to radiation-induced 
444 defects (RID) which also occurs in the $\mathrm{g}=2$ region. Various RIDs can be formed within the

445 kaolinite structure (Clozel et al., 1994 ; Allard et al., 2012). In the investigated samples, this 446 spectrum mainly corresponds to that of the A-center with signals at $\mathrm{g}=2.049(\mathrm{~g} / /)$, and $\mathrm{g}=$ $4472.006(\mathrm{~g} \perp)$ (Fig. 5). This center consists in an electron hole located on an oxygen atom (Angel 448 et Jones, 1964; Clozel et al., 1994), produced by natural ionizing radiation ( $\alpha$, $\beta$ and $449 \quad \gamma$ radiations).

\section{Calculation of kaolinite ages}

Because of their thermal stability, A-centers accumulate in the kaolinite structure since its crystallization and can be used as a geochronometer consistent with geological time scales (Balan et al., 2005; Allard et al., 2018; Mathian et al., 2018). The kaolinite dating involves three steps: (i) measurement of the EPR signal intensity of A-center in the collected sample, (ii) determination of the natural radiation dose that affected these kaolinites since their cristallisation (the so-called paléodose), (iii) interpretation of the paleodose in the light of the natural radiation dose rate, enabling the determination of kaolinite age. Step (ii) requires the determination of the relation between the signal intensity of A-centers and the radiation dose

\subsection{Intensity of A-center signal}

466

467 The intensity of the $\mathrm{g} \perp$ component is used to estimate the variations of A-center concentration

468 in kaolinite sample. As it interferes with the most intense resonance of the vanadyle spectrum

469 (Fig. 5), vanadyle contribution has been corrected by a linear extrapolation using the $\mathrm{VO}^{2+}$ band 470 located at $\mathrm{g}=1.881$ (only attributed to $\mathrm{VO}^{2+}$ ) and a reference spectrum with dominant $\mathrm{VO}^{2+}$ 471 signal (dimex dickite; Balan et al. 1999; Premovic et al., 2011), as expressed in equations 2 and 4723.

475 where $I_{\text {zdim }}$ is the normalised intensity of the signal at $g=1.881$ of the EPR spectrum of dimex

476 sample and $\mathrm{I}_{\mathrm{zs}}$ : the normalised intensity of the same signal in the EPR spectrum of the studied 477 sample (Figure $5 \mathrm{~A}, \mathrm{~B})$. 


$$
I_{R I D}=T I_{S}-T I_{d i m} \times R_{V O^{2}}
$$

480

481

482

Where $\mathrm{I}_{\mathrm{RID}}$ is the EPR signal intensity of A-centers, TIs is the normalized intensity of the EPR signal at $\mathrm{g}=2.006$ of the studied sample and $\mathrm{TI}_{\mathrm{dim}}$ is the normalized intensity of the signal at $\mathrm{g}=2.006$ of the dimex sample (Fig. 5 A, B).

The initial $g=2.006$ intensity and the obtained RID intensities ( $\left.\mathrm{I}_{\mathrm{RID}}\right)$ are both presented in the SI 6. The resulting calculated intensities related to A-center range between 0.24 to 5.58 arbitrary units (A.U.) for the Ferralsol CA, and 0 to 21.23 A.U. for the Acrisol CO2.

\subsection{Paleodose determination}

Four samples from the Ferralsol profile (CA 84, CA 200, CA 440, CA 480) and four from the Acrisol profile (CO2 45, CO2 200, CO2 280, CO2 450) have been selected for artificial irradiation (Table 1). The resulting dosimetry curves have been fitted using an exponential function (Allard et al., 1994) combined with a linear parameter (F1), as described in Duval (2012) and Allard et al. (2018), to enhance the fit precision:

$I=I^{\infty \times}\left(\mathbf{1}-\boldsymbol{e}^{-\boldsymbol{\mu}(\boldsymbol{D}+\boldsymbol{P})}\right)+\boldsymbol{F 1} \times(\boldsymbol{D}+\boldsymbol{P})$

where $I$ is the RID concentration, $I_{\infty}$ is the RID concentration at saturation, $\mu$ is an efficiency factor, $\mathrm{P}$ is the natural paleodose, $\mathrm{D}$ is the artificial dose rate and $\mathrm{F} 1$ is a linear factor.

The fitting parameters of dosimetry curves are presented in the SI 7. The paleodoses (Tables 2 and 3) range from 1.21 $1_{+-0,24} \mathrm{kGy}$ to $27.59_{++-, 81} \mathrm{kGy}$ for the Ferralsol CA (Fig. 6A), and $23.92_{++6.54}$ to $100.92_{++2.7 .32} \mathrm{kGy}$ for the Acrisol CO2 (Fig. 6B). The errors on the paleodose have been calculated using a Monte Carlo simulation based on an experimental error of $15 \%$ on each point of the curve data set as described in Mathian et al. (2018).

Paleodose estimation for non-irradiated samples were performed using the approach of Balan et al. (2005) and Mathian et al. (2018). It is based on the assumption that kaolinites with a similar disorder will accumulate radiation-induced defects according to a same dosimetry function (Allard et al., 1994). The fitting parameters of the dosimetry curve from the irradiated 
512 kaolinite were extrapolated to the ones with a similar disorder, providing an estimate of 513 paleodose. The group of extrapolations are detailed in the Tables 2 and 3: the CA 84, CA 200, 514 CA 440, CA 480 fitting parameters have been used, for CA1, CA2, CA3 and CA4-types kaolinites, respectively. Concerning CO2, the parameters of CO2 45, CO2 200, CO2 280 and $\mathrm{CO} 2450$ have been used for the $\mathrm{C} 1 \mathrm{C} 2, \mathrm{C} 3$ and C4-types kaolinites, respectively.

517

Note that differences in the kaolinite/gibbsite ratio between samples of the same disorder family cause a slight underestimation of the paleodose for samples containing more gibbsite than their irradiated reference (as for $\mathrm{CO} 255$ ) and overestimation for the reverse case (as for CA 240 and 280 samples). Beside this incertitude, the extrapolation methodology also induces an additional error on the estimated paleodose (Mathian et al., 2018), which is added to the errors related to the determination of initial dosimetry curves. Accordingly, ages determined on extrapolated samples are less accurate than those obtained on irradiated samples.

\subsection{Dose rate determination}

The dose rate of each sample was calculated using the formula from Aitken (1985) and the concentrations from $\mathrm{U}$, Th and $\mathrm{K}$ (Table 2 and 3). Note that due to the small amount of sample, the bulk chemistry of CO2 405, CA 485 and 380 samples has not been analyzed and no age can be given for these samples.

The dose rate of the cosmic rays is small and decreases exponentially within the first soil meter (Aitken, 1985), and was neglected for these calculations. The resulting uncorrected dose rate range from $29.18_{++2.2 .}$ to $70.87_{++3.35} \mathrm{~Gy} / \mathrm{ka}$ for the Ferralsol profile (CA) samples and from $19.62_{++1.14}$ to $46.93_{++2.29} \mathrm{~Gy} / \mathrm{ka}$ for the Acrisol profile (CO2) (Table 2 and 3).

However, the dose rate inferred from chemical composition is a raw value and does not directly correspond to efficient natural irradiation of kaolinites because of three main factors: 1) the role of the spatial distribution of radioelements in the external irradiation of kaolinite; 2) potential radon escape; 3) attenuation effects related to the water content of the soil samples. These three factors can decrease the dose rate actually experienced by kaolinites with respect to that inferred from chemical compositions only. Corresponding corrections of raw dose rates have been introduced as follows: 
(1) The average mean free path of alpha particles in silicates is about $20 \mu \mathrm{m}$.

547 Consequently, the alpha particles emitted from the uranium included in larger U-bearing 548 minerals, relatively stable under tropical weathering conditions, do not participate to the A549 center defects formation within the bulk kaolinite sample. To estimate the proportion of $U$ 550 hosted in such U-bearing minerals induced-fission tracks mapping was performed on two thin 551 sections of resin embedded samples from each profile: CA 65 and CA 130, two undated blocs 552 samples representative of the top and bottom Ferralsol respectively, CO2 87 representative of 553 the Acrisol samples and another considered as representative of the bottom profile localized at 554 a depth of ca $130 \mathrm{~cm}$ and named after as "CO 3875 ".

555 The fission tracks maps show that a large part of uranium is localized in relatively scarce hot 556 spots characterizing U-bearing minerals. They can be zircon grains, characterized by stars557 shaped hot spots, or iron/titanium oxides, characterized by larger and more diffuse spots (see 558 Balan et al., 2005). The distribution of fission tracks through the Ferralsol profile exhibits a 559 slight decrease of $U$ contained in U-bearing minerals from the bottom to the top of the profile 560 (Table 2 and SI 7) as $51 \%$ of the fission tracks are contained within these minerals in the top 561 samples and $65 \%$ in the bottom samples. A similar trend is observed within the Acrisol profile 562 (CO2) (Table 3 and SI 8). The top soil samples have about 55\% of uranium spread out in the 563 clayey matrix, adsorbed on phyllosilicates or oxides/oxyhydroxides and this proportion is $c a$ $56429 \%$ for the bottom samples. This suggests a dissolution/depletion of U-bearing minerals within 565 both soil horizons, as their size and number decrease from the bottom samples to the top ones.

566 Based on these observations, the dose rate was corrected by removing the alpha contribution 567 from the $\mathrm{U}$ contained in U-bearing minerals. It was considered that $\mathrm{Th}$ is distributed homogeneously in the samples matrix, possibly as insoluble Th oxides (Langmuir \& Herman, 1980), as in Balan et al. (2005) and Mathian et al. (2018). The accumulation of such Th oxides in the top Acrisol profile (Th: ca 40 ppm) and at the base of the Ferralsol (Th: ca 30 ppm) may explain the increase of Th content in these parts of the profiles.

(2) Laterites, and more generally soils, are open geochemical systems often characterized by some disequilibrium of $U$ and Th decay chains (Dequincey et al., 2002; Balan et al., 2005). Disequilibrium can induce major changes in the total dose rate arising from uranium and daughter elements (Aitken, 1985). Gamma spectrometry was performed on representative samples from each profile to estimate this disequilibrium. The CA 84 sample is assumed to be representative of the Ferralsol profile, CO2 200 representative of the Acrisol solum and $579 \mathrm{CO} 2450$ of the Acrisol saprolite. At secular, equilibrium, all radioactive elements have an 
580

581

582

583

584

585

586

587

588

589

590

591

592

593

594

595

596

597

598

599

600

601

602

603

604

605

606

607

608

609

610

611

612

equivalent activity. A special attention is given to ${ }^{238} \mathrm{U}$ and ${ }^{222} \mathrm{Rn}$ activity variation within each sample because radon losses are described as one of the most current sources of disequilibrium of decay chains (Aitken, 1985; Ozkowski et al., 2000). Gamma spectrometry does not indicate radon losses but an equilibrium state for the Ferralsol (CA) sample and radon accumulation of 17 and 36\% for the Acrisols profile samples CO2 200 and CO2 450, respectively (Table 4). This suggests a possible recent leaching of $U$ within the Acrisol (CO2) profile. This radon accumulation was used to correct the dose rate by adding a contribution of ${ }^{222} \mathrm{Rn}$ and daughter products equivalent to its percentage of accumulation.

(3) In addition to the above correction, the water content of soil has an significant effect on the dose rate received by a soil kaolinite (Hennig et Grün, 1983; Allard, 1994). Local studies have shown that the low vertical water drainage of the Rio Negro soils is the cause of an important residence time of water in the soil (Rozanski et al., 1991). Bruno et al. (2006) have estimated average volumetric soil moisture of $0.38 \mathrm{~m}^{3} / \mathrm{m}^{3}$ in the dry season minimum to 0.56 $\mathrm{m}^{3} / \mathrm{m}^{3}$ in the humid season maximum for soils of the Amazon basin. It roughly corresponds to average weighted water content of 0.2 for the local soil. The previously calculated dose rates are thus corrected using the formula of Hennig et Grün (1983).

$$
D_{H 2 O}=D \alpha \times(1+1.49 W)^{-1}+D \beta \times(1+1.25 W)^{-1}+D \gamma \times(1+W)^{-1}
$$

where $\mathrm{W}$ is a weighed water content (between 0 and 1 ), $\mathrm{D}_{\mathrm{H} 2 \mathrm{O}}$ the dose rate of the humid sample, $\mathrm{D} \alpha, \mathrm{D} \beta$ and $\mathrm{D} \gamma$ respectively the alpha, beta and gamma corrected dose rates of the sample.

The evolution of corrected dose rates with depth follow a different trend in each profile, (Fig. 7B). In the Ferralsol profile (CA), the dose rate decreases from the bottom to the top of the saprolite (excluding the peculiar CA 480 sample) and is almost constant in the soil. The dose rate trend observed in the saprolite reflects a decrease in Th and $U$ concentration (Fig. 7A), likely related to the dissolution of U-bearing minerals as suggested by fission tracks analyses. In the Acrisol profile (CO2), the dose rate only displays comparatively weak variations as a function of depth, excepted three Th-rich samples of the soils. The U concentration in the soil is stable and smaller than that observed in the Ferralsol, where it is also relatively stable (about $1 \mathrm{ppm}$ of variation). The important Th evolution in the Acrisol saprolite (about $10 \mathrm{ppm}$ of variation) is linked to a lower $U$ variation (about $3 \mathrm{ppm}$ variation). It points to the fact that this saprolite is a more mature weathered material than the one of the Ferralsol, in which both $U$ 
613

614

615

616

617

618

619

620

621

622

623

624

625

626

627

628

629

630

631

632

633

634

635

636

637

638

639

640

641

642

643

644

645

and Th have an important range of evolution. These results confirm that each part of both soils is not only characterized by specific mineralogy and characteristics of kaolinite but also by its own geochemical dynamics.

\subsection{Distributions of kaolinite ages}

The kaolinite ages have been obtained as the ratio of the paleodose to the corrected dose rate (Tables 2 and 3). The ages range from $0.02 \mathrm{Ma}$ to 5.98Ma. Kaolinites with ages below 0.25 Ma have just been indicated as "quaternary" kaolinites, owing to the large uncertainty of young age (Fig. 8).

Despite different crystal-chemical characteristics, kaolinites from the two solums have a similar age in both profiles, ranging from ca 2 Ma to 1 Ma (Fig. 8). Kaolinites from the Acrisol saprolite are older (6 Ma to 3.6 Ma) than the ones from the Ferralsol saprolite $(<1 \mathrm{Ma})$. It is also noteworthy that the transition between the Acrisol soil horizons and the saprolite displays very recent kaolinites. It may indicate a recent activation of soil/saprolite transformation front described by Nahon et al. (2003) for example. These ages are fully consistent with mineralogy, geochemistry and kaolinite disorder variation: the saprolites and soils are different subsystems. The kaolinites ages and their distribution in both profiles confirm that they formed and evolved owing to different temporality. This supports the mineralogical and geochemical results of this study, that highlight the distinction between Acrisols and Ferralsols in the Curicuriari area as well as between saprolite and solum in each weathering cover.

\section{Discussion}

\subsection{Weathering fronts in the investigated profiles}

The present study brings evidence that two contrasting regolith profiles contain several types of kaolinites with different ages and crystal-chemical characteristics. Similar findings have been reported for other laterite profiles (e.g. Balan et al., 2005; Allard et al., 2018; Mathian et al., 2018). In unconsolidated tropical soils developed at the expense of kaolinite-rich sediments in the Amazon basin (Lucas et al., 1987; Giral-Karmacik et al., 1998; Balan et al., 
2005; Balan et al., 2007), kaolinites are characterized by a decrease of the structural order and particle size from the bottom to the top of the profile. This evolution was interpreted as reflecting the mixing of two kaolinite generations in a proportion continuously varying with depth, indicating the progressive replacement of sedimentary kaolinite by secondary kaolinites along the profile due to the action of one weathering front (Balan et al., 2007).

In the present data set, the kaolinites ages in the saprolite ( $\mathrm{C}$ horizon) of the Ferralsol profile (Caju profile) tend to increase from bottom to top and attest for the recent formation of kaolinite. This is consistent with the action of a vertical weathering front acting at the saprolite/primary rock contact. This front may still be active, confirming that some laterites profiles could also formed/evolved under the present-day climatic conditions. In contrast, kaolinites ages of the Ferralsol solum are relatively homogeneous and older than the saprolite ones. This general trend is consistent with a classical per descensum model of soil formation. It may also be related to the concepts of soil catena (e.g. Yoo and Mudd, 2008 and references therein). In this concept, soils from an hillslope are interconnected and one soil receives particles from other soils upslopes but also provides particles to the soils downslopes. Accordingly, a soil profile from an hillslope can be divided into an immobile part, that can roughly correspond to the saprolite and the bottom part of the profile solum, and a mobile part that can be named the "soil conveyor belt". In this soil system, young soils particles formed at the saprolite/primary rock contact move upward, in parallel of the soil formation and erosion. They are then translocated downward when they reach the conveyor belt. According modelling studies (see Anderson et al., 2015 for example), the particles ages within a soil profile are younger and more dispersed in the bottom of this type of profile than in the conveyor belt. This is consistent with the kaolinites ages organization within the ferralsol and can also explain the gap of ca $0.5 \mathrm{Ma}$ between the three top kaolinite samples and the ones close to solum/saprolite transition. However, due to the location of this Ferralsol, at the top of its local slope, our data do not allow one to distinguish between this model and in situ formation of kaolinite in the Ferralsol profile without translocation of soil particles.

A contrario, the Acrisol (CO2 profile) displays an "inverse" kaolinite ages succession, with younger kaolinites in the top soil and older in the saprolite. This age distribution may be considered as characteristic of a partly rejuvenated fossilized and non active laterite profile (e.g. Mathian et al., 2019). Indeed, this shows that the Acrisol solum formed at the expense of materials weathered during a previous stage of profile development. This interpretation is consistent with the stronger $U$ depletion observed in the Acrisol profile, compared with the 
680 Ferralsol. The ages trend of this profile and its location on a plateau tends to demonstrate that 681 the local Acrisol are not impacted by the presence of a soil conveyor belt. In addition, the dating

682

683

684

685

686

687

688

689

690

691

692

693

694

695

696

697

698

699

700

701

702

703

704

705

706

707

708

709

710

711

712

713 of secondary minerals of this profile cannot confirm the action of soil particle translocation process. Absence of cutanes on soils particles in thin sections also confirms this observation. Weakness of translocation evidence should be linked to local low erosion rates, low water fluid horizontal circulation and to the dissolution of the oldest kaolinites of this profile.

In both profiles, the soil/saprolite transition is characterized by a relatively steep variations in geochemistry and mineralogy and in characteristics of kaolinites, most especially their age. This supports the idea that this transition coincides with a weathering front, as suggested by Nahon (2003). In the Acrisol profile, the quaternary kaolinite age observed at the soil/saprolite transition may correspond to a recent reactivation of the corresponding weathering front. The presence of several generations of kaolinites within an unconsolidated soil profile, demonstrated by these data and the previous EPR dating study of kaolinites (Balan et al., 2005; Allard et al., 2018; Mathian et al., 2019), and their erasure or persistence linked to weathering events, is a confirmation of soil polygenesis as defined by Richter and Yaalon (2012). Shifting environment (climate, vegetation, hydrology) and microenvironment impacts and transforms a soil profile during its life and will causes erasure of some of its features, here the dissolution of kaolinite generations for example, while others are preserved. An old unconsolidated soil, as the acrisol profile presently studied, will display features characteristic of the environment variations that occurred since its formation. EPR dating reveals various relicts of secondary clay minerals that resisted to strong successive weathering episodes having occurred since their formation. This study thus confirms that unconsolidated soils can be considered as "memory of the landscape" as explained by Richter and Yaalon (2012) and references.

\subsection{Relation with paleoclimates}

The presence of distinct generations of secondary minerals within a same regolith indicates that several precipitation/dissolution events have affected specific parts of the profile which is in line with the observations of Lucas et al. (1996) and Girard et al. (2002). Dating studies of secondary minerals in laterites have shown that these phenomena are often linked to the succession of specific preferential weathering periods or weathering pulses. These events cause the formation of large quantity of secondary minerals that can mask or overprint the signal 
of continuous weathering recorded within a regolith mineralogy. Relictual secondary minerals

715 (i.e. secondary minerals formed during a former weathering event preserved from the following rejuvenation processes) are, in most cases, witnesses of several events (Vasconcelos, 1999; Balan et al., 2005; Retallack et al., 2010; Bonnet et al., 2016; Miller et al., 2017; Allard et al., 2018; Mathian et al., 2018). However, their discrete instead of continuous ages suggest that they are mainly related to intense precipitation periods. During these periods, large amounts of old kaolinites may be dissolved to form the observed large amount of renewed kaolinites. These type of weathering events may also be linked to eustatic variations and tectonic activities that can impact both continental erosion, increasing the regolith rate formation, and the watertable position, acting as a local base level. The watertable is divided in two hydrological zones (Ollier et al., 1988): the zone of discharge, in which the water flows and displays undersaturated compositions with respect to the secondary and primary minerals, and the stagnant zone in which the efficiency of primary mineral weathering is lowered because of near-equilibrium conditions between minerals and aqueous solutions. The closer the watertable to the top, the less the regolith volume interacts with undersaturated aqueous solutions. A contrario a watertable closer to the regolith base corresponds to a larger regolith volume interacting with undersaturated aqueous solutions. These phenomena should decrease or increase, respectively, the vulnerability of soils to rejuvenation processes impacting their secondary minerals. Note that the weathering front depth is often decoupled from the water table depth in regolith profile (Braun et al., 2016). Both punctual weathering periods (i.e. precipitation related/ watertable lowering related) erase the record of less intense weathering episodes, which implies that the dating of kaolinite, in most cases, do not date the beginning of a profile formation.

Two main periods of formation for kaolinites have been identified (Fig. 9): ca 6-3.6 Ma, in the Acrisol saprolite, and 2.5 Ma to the recent period. This last may be divided in two: 1) the one ranging from 2.5 to $1 \mathrm{Ma}$ for both the Acrisol and Ferralsol; 2) the one varying from ca 0.9 Ma to the recent periods, recorded in the Ferralsol saprolite and at the soil/saprolite transition

741 of the Acrisol profile. Both periods can be linked to major paleosurfaces identified in South 742 America using paleomagnetism and other dating methodologies used during the last three decades (Bardossy and Aleva, 1990; Vasconcelos et al., 1994; Retallack, 2010; Leonardi et al., 2011 and ref. therein; Monteiro et al., 2014; Allard et al., 2018; Theveniaut \& Freyssinet 1999; 2002). 
regional climatic or geodynamic events that caused a local precipitation pulse (see Mathian et al., 2019); 2) response to global water base level dropping (Haq et al., 1987) that drastically increased continental erosion, and lowered the local watertable levels but could also impact a larger part of the Amazon Basin. Enhanced drainage efficiency directly affects the formation of regolith (Braun et al., 2016), possibly reactivating the weathering fronts in the profiles.

Concerning the first origin, several regional climatic events may coincide with the formation of kaolinite generations in the studied profiles. The first weathering period, extending from $6 \mathrm{Ma}$ to $3.6 \mathrm{Ma}$, is recorded in the Acrisol saprolite. This generation of kaolinites may be linked to the one observed in the Manaus laterites (Balan et al., 2005), as well as to some duricrust samples from the Rio Negro basin (Allard et al., 2018). From a geomorphologic point of view, it would be related to the end of late Velhas paleosurface of South America as defined by Bardossy and Aleva (1990). The beginning of this period, younger than the pan-Amazonian Ucayali Peneplain (ca 9.5/9 Ma), coincides with the last Quechua Andean uplift event (Quechua III) observed in the sedimentary records by Campbell et al., (2006). The literature explained that the Amazon lowland climate became humid since the Quechua I event (ca 17-15 Ma) during which the Andean height (ca $2 \mathrm{~km}$ ) was sufficient to modify the air circulation over South America (Campbell et al., 2006; Insel et al., 2009). No kaolinite from this period was found in the studied profiles. Even if the global Earth climate was relatively cold during the Quechua III period (Zachos et al., 2001), this Andean uplift has potentially influenced the intensity of the rainfall in the north west of the Amazon Basin, already governed by a monsoon climate (Vonhof et Kaandrop, 2010 and ref. therein). Indeed, this tectonic phenomenon was described as increasing the monsoon seasonality over Amazonia by Sepulchre et al. (2010). Consequently, the Acrisol saprolite kaolinite generation may result from a period of weathering intensification over at least the northwestern part of Amazonia. The most recent kaolinites of this phase are around $4 \mathrm{Ma}$. This period could have stopped with the potential slight fall of precipitation and temperature in the Amazon basin linked to the Panama isthmus closure (Rosetti et al., 2004). However, some iron oxides from duricrusts of the Curicurari and Manaus region crystallized during this time period (Allard et al., 2018). These results contradict the idea of a global decrease of precipitations in northwest Amazonia. The global warm period of the Mid-Pliocene (ca 3.3-3 Ma, Haywood et al., 2016) is apparently not recorded in the two studied unconsolidated profiles.

\footnotetext{
Two main weathering periods can be identified during the Pleistocene, one from 2.5 to $1 \mathrm{Ma}$
} 
that corresponds to the formation/rejuvenation of both studied Acrisol and Ferralsol solum and a latter one from 0.9 to the present that corresponds to the Ferralsol saprolite. The first period has also been recorded within a duricrust of the Rio Negro basin (Allard et al., 2018), possibly formed during a base level dropping as it is today located below the river level. The second Pleistocene weathering period (less than $1 \mathrm{Ma}$ ) has also been identified in Amazonia by Vasconcelos et al. (1994). Both periods can be correlated with the Quaternary Paraguaçu weathering surface (King, 1956; Bardossy and Aleva, 1990). No regional geodynamic-linked climatic events can be linked with these preferential periods of weathering. However, the Amazonian climate since the Miocene, and particularly during the Quaternary, was dependent on the Intertropical convergence zone migration (Harris \& Mix, 1999; Vonhof \& Kaandrop, 2010). The ICTZ position depends on Milankovitch cycles and is accordingly linked to global Earth climate. Aris \& Mix (1999) explained that the ICTZ migration through the Quaternary has caused a succession of arid climates in Amazonia during the ice age periods, and hot and warm climate during the interglacial periods. Consequently, the quaternary kaolinites from both profiles may have developed through these last humid periods. However, due to its limited precision, the EPR dating methodology cannot precisely identify their succession.

Concerning the second hypothesis, several important global sea level falls have been observed since 10 Ma by Haq et al. (1987) and Miller et al. (2005). These events will be reflected on the continent by a global base level dropping that likely caused the lowering of the Curicuriari watertable depth and also increase the regional erosion. Even if 7 sea levels events (ca $8 \mathrm{Ma}$, 6.2 Ma, 5.5 Ma, 4 Ma, 3 to $2 \mathrm{Ma}, 1.5 \mathrm{Ma}$ and 1 to actual Ma) have been recorded within sedimentary basin by Haq et al. (1987), it is difficult to compare the ages of both profiles rejuvenation episodes to a precise event of this kind. Indeed, the speed of upstream advance of incision waves from the Atlantic ocean to the upper Amazon lowland is unknown. However, the influence of these events on the birth and propagation of secondary weathering fronts must be considered. Thus, the modern incision trend of the plateaus edges, allowing the Ferralsol (CA) development, could also be a response to the last sea level drop (ca 100ka, Miller et al. 2005) impacting the Curicuriari region base level. A contrario, the direct impact of the Andean uplift on the local base level (watertable depth and rivers level) appears as less likely due to the distance between the Curicuari basin and the Andes. However, it caused the development of the modern Amazon drainage system at the Late Miocene and beginning of Pliocene (see Mora et al., 2010 and references). The development of this erosional system and its change on the local hydrology, may also be correlated to the initial formation of the Acrisol saprolite found 
on the Curicuriari plateaus.

\subsection{The Ferralsol/Acrisol transition}

819

820

821

822

823

824

825

826

827

828

829

830

831

832

833

834

835

836

837

838

839

840

841

842

843

844

845

846

847

848

849

The present study highlights major differences between the Acrisol and the Ferralsol. The yellowish Acrisol contains kaolinite and goethite from the bottom to the top profile but the kaolinite content decreases in the soil toward the surface. This clay depletion is a major step for Acrisol formation in former models of weathering covers evolution in the Amazon Basin (Fritsch et al 2011; Melfi et al. 1996). By contrast, the mineralogical evolution of the Ferralsol can be described by a kaolinite accumulation from the top saprolite to the top soil. Indeed, early products of weathering formed in this profile are gibbsite and hematite, that indicates a high and low water activity in the soil, respectively (Beauvais et Tardy, 1991; Beauvais et al., 2009). The presence of gibbsite as one of the earliest secondary minerals can be considered as a common feature during the weathering of well-drained Al-rich rocks, forming fluids easily saturated with respect to gibbsite, (Anand et al., 1985; Herrmann et al., 2007; Shvartsev, 2012) and has also been observed in other sites from Brazil (Dubroeucq and Volkoff, 1988; Lucas et al., 1996; Furian et al., 2001). Gibbsite is then replaced by kaolinite in the top profile, probably linked to quartz dissolution, as suggested by the Si geochemical trend (SI 3) and a lower water activity in the top profile.

Kaolinites in the Ferralsol and Acrisol soils have similar ages. Accordingly, no data of this study support the idea of the local transformation of the present day Ferralsol into the Acrisol, as could eventually be expected in a context of a "yellowing front" as was observed in the Manaus area (Fritsch et al., 2011). This process, a transformation of a red Ferralsol toward a yellow one, was interpreted as a vertical mineralogical transformation within a profile due to the present days warm and humid climate. Based on the chronology established in the present study, both type of solum could correspond to the same weathering events having affected different types of materials: weathered materials, preserved in its saprolite, for the Acrisol and fresher rock for the Ferralsol. This interpretation is consistent with the occurrence of Ferralsols on incised plateau edge, favoring the erosion of ancient weathering products along the slope and valley. These ages are consistent with the local geomorphological observations (Taitson Bueno, 2009) showing the extension of recent Ferralsol domains at the expense of older Acrisols in parallel of plateau erosion. In this case, erosion and quaternary weathering of fresh rock tends to be the main process guiding the replacement of Acrisol by Ferralsol. However, a lower elevation of the Ferralsol derived from fresh rock could be expected. In addition, our 
850

851

852

853

854

855

856

857

858

859

860

861

862

863

864

865

866

867

868

869

870

871

872

873

874

875

876

877

878

879

880

881

mineralogical and kaolinite dating data cannot confirm the idea that the local Ferralsol solum replace Acrisol solum due to a desilification process affecting the kaolinite as both have kaolinite with a similar age.

An alternative scenario can be proposed from the age organization and mineralogy of both profiles. Indeed, gibbsite, is present in low amount in the acrisol solum and in increasing amounts from the Ferralsol solum to the Ferralsol saprolite. It can suggest a mineralogical and geochemical filiation between the two profiles. In this case, the original material of the present day Ferralsol profile and Acrisol solum could be the relictual Acrisol saprolite that covered the plateau. This saprolite was submitted, during the Quaternary, to an intense weathering episode that continued until present time on the incised edges of the plateau, and transformed its parent material at least on $5 \mathrm{~m}$ deep, because of increased drainage conditions. On the plateau, this weathering front exists also between the solum and the saprolite of the Acrisol, albeit with limited extent: it may be delayed, owing to unfavourable drainage conditions produced by the clay-rich horizons. In this scenario, rejuvenation of older kaolinite generations is central and relies on the modification of the hydrological properties of the profiles together with progressive Si leaching and erosion. Consistently, the Si content in the Ferralsol is 10 to $20 \%$ lower than in the Acrisol.

In the Curicuriari Basin, both Ferralsol and Acrisol can be replaced by Podzols which are observed to form at the center of the plateaus over the inundated plains and depressions (Dubroeucq et Volkoff, 1998; Do Nacscimento et al., 2004; Fritsch et al, 2011 and ref. therein; Ishida et al., 2014) and over the slopes of river incisions (Lucas et al., 1996). Moreover, it is not excluded that the transformation of an old Ferralsol into the present-day Acrisol, described in the model of Taitson Bueno (2009), occurred earlier than 6 Ma. However, our study did not reveal relictural parts of tertiary ferralsols within the acrisol.

\section{Conclusion}

This study provides new absolute ages kaolinite formation in Acrisol and Ferralsol, that belong to common weathering covers in the upper Amazon Basin. Both types of soils are the result of different processes linked to the topography evolution and possibly to their respective soil drainage conditions. The present data set confirms and specifies the initial geomorphological model by Taitson Bueno (2009). It also confirms that soil and saprolite are distinct systems, owing to their mineralogy, crystal chemistry and ages of kaolinites. 

lateritic profiles contain several generations of kaolinite that have recorded the signature of discrete preferential weathering periods consistent with climatic variations. At least 3 events are recognized: one recorded in the Acrisol saprolite between ca 6-3.6 Ma, one that renewed the Acrisol solum and potentially triggered the Ferralsol formation between 2.5 to ca $1 \mathrm{Ma}$ and a last event that is only revealed in the Ferralsol saprolite between $1 \mathrm{Ma}$ and present. The recorded weathering periods coincide with major paleoclimatic events. The first weathering period may have been triggered by the impact of Quechua III event on Amazonian monsoonal system and may have stopped after an aridification of this region linked to the impact of the Panama closure on climate. The two others might result from ITCZ migration due to Milankovitch cycles succession. The influence of variation of water base level may also be relevant, but it is difficult to establish owing to the insufficient precision of EPR ages. In line with other dating studies, these results confirm that upper Miocene to Quaternary periods were favourable to the laterite development over the Amazon basin.

\section{Bibliography}

\section{Acknowledgements}

Support by M. Guillaumet, L. Delbes, K. Béneut and the IMPMC spectroscopy and XRD platforms is acknowledged. We thank the anonymous reviewers for their pertinent comments.

Aitken, M.J. (1985) Thermoluminescence dating. Studies in archaeological science. Academic Press, London (359 pp).

Allard, T., Muller, J.P., Dran, J.C., Ménager, M.T. (1994) Radiation-induced paramagnetic defects in natural kaolinites : alpha dosimetry with ion beam irradiation, Physics and chemistry of minerals, 85-96.

Allard, T., Balan, E., Calas, G., Fourdrin, C., Morichon, E., Sorieul, S. (2012) Radiation induced defects in clay minerals : A review, Nuclear Instruments and methods in physics research, 112-120.

Allard, T., Gautheron, C., Riffel, S.B., Balan, E., Soares, B.F., Pinna-Jamme, R., Derycke, A., Morin G., Bueno, G.T., do Nascimento, N. (2018) Combined dating of goethites and kaolinites from ferruginous duricrusts. Deciphering the Late Neogene erosion history of Central Amazonia, Chemical Geology, 479, 136-150.

Almeida, M.E. (2005) Reconhecimento geológico ao longo do baixo curso do rio Curicuriari, noroeste do Estado do Amazonas, CRPM.

Anand, R.R., Gilkes, R.J., Armitage, T.M., Hillyer, J.W. (1985) Feldspar weathering in lateritic saprolite, Clays and Clay Minerals, 33 (1); 31-43.

Anderson et al. (2015) Particle trajectories on hillslopes: Implications for particle age and 10Be structure. Journal of Geophysical Research: Earth Surface, 120, 1626-1644.

Angel, B.R., Jones, J.P.E., Hall, P.L. (1974) Electron spin resonance studies of doped synthetic Kaolinite I. Clay Minerals, 10, 247-255.

Balan, E., Allard, T., Boizot, B., Morin, G., Muller, J.P. (1999) Structural Fe ${ }^{3+}$ in natural kaolinites: new insights from electron paramagnetic resonance spectra fitting at X and Q-band frequencies. Clays and Clay Minerals, 47 (5), 605-616. 
Balan, E., Allard, T., Boizot, B., Morin, G., Muller, J.P. (2000) Quantitative measurement of paramagnetic Fe3+ in kaolinite. Clay and Clay minerals, 48 (4), 439-445.

Balan, E., Saitta, A.M., Mauri, F., Calas, G. (2001) First-principles modeling of the infrared spectrum of kaolinite, American Mineralogist, 86, 1321-1330.

Balan, E., Fritsch, E., Allard, T. \& Calas, G. (2005) Formation and evolution of lateritic profiles in the moddle Amazon basin : Insights from radiation-induced defects in kaolinite, Geochimica and Cosmochimica Acta., 69 (9), 2193-2204.

Balan, E., Lazzeri, M., Morin, G., Mauri, F. (2006) First-principles study of the OH stretching modes of gibbsite. American Mineralogist, 91, 115-119.

Balan, E., Fritsch, E., Allard, T. \& Calas, G. (2007) Inheritance vs. Neoformation of kaolinite during lateritic soil formation : a case study in the middle Amazon Basin. Clays and Clay minerals, 55 (3), 253-259.

Balan, E., Delattre, S., Guillaumet, M., Salje, E. (2010) Low-Temperature infrared spectroscopic study of OHstretching modes in kaolinite and dickite. American Mineralogist, 95 (8-9), 1257-1266.

Bardossy, G., Aleva, G.J.J. (1990) Lateritic bauxites. Dev. Econ. Geol., 27, 624.

Bartoli, G., Sarnthein, M., Weinelt, M., Erlenkeuser, H., Garbe-Schönberg, D., Lea, D.W. (2005) Final closure of Panama and the onset of northern hemisphere glaciation. Earth and Planetary Science Letters, 237, 33-44.

Beauvais, A., Tardy, Y. (1991), Formation et dégradation des cuirasses ferrugineuses sous climat tropical humide, à la lisière de la forêt équatoriale. Comptes Rendus de l'Académie des Sciences, Séries II 13, 1539-1545

Beauvais, A., Ruffet, G., Hénocque, O., Colin, F. (2008) Chemical and physical erosion rhythms of the West African Cenozoic morphogenesis: the ${ }^{40} \mathrm{Ar}-{ }^{39} \mathrm{Ar}$ of supergene K-Mn oxides. Journal of Geophysical Research, 113 , F04007.

Beauvais, A. (2009) Ferricrete biochemical degradation on the rainforest-savannas boundary of Central African Republic. Geoderma, 150, 379-388.

Billups, K, Ravelo, A.C., Zachos, J.C., Norris, R.D. (1999) Link between oceanic heat transport, thermohaline circulation and the Intertropical Convergence Zone in the early Pliocene Atlantic. Geology, 27, 319-322.

Bland W., Rolls D (1998) Weathering: An introduction to the scientific principles. London: Routledge, 288

Bonnet, N.J., Beauvais, A., Arnaud, N., Chardon, D., Jayananda, M. (2016), Cenozoic lateritic weathering and erosion history of Peninsular India from 40Ar/39Ar dating of supergene K-Mn oxides, Chemical Geology, 446, 33-53.

Bookhagen, B., Strecker, M.R. (2010). Modern Andean rainfall variation during ENSO cycles and its impact on the Amazon drainage basin. Amazonia, Landscape and Species Evolution: A look into the Past., 1 st edition. Edited by C. Hoorn and F.P. Wesselingh, Chapter thirteen.

Bookhagen, B., Strecker, M.R. (2008). Orographic barriers, high resolution TRMM rainfall, and relief variations along the eastern Andes. Geophys. Res. Lett., 33

Braun, J., Mercier, J., Guillocheau, F., Robin, C. (2016) A simple model for regolith formation by chemical

weathering. Journal of Geophysical Research: Earth Surface, 121 (11), 2140-2171

Bruno, R.D., da Rocha, H.R., de Freitas, H.C., Goulden, M.L., Miller, S. (2006) Soil moisture dynamics in an eastern Amazonian tropical forest. Hydrological Processes, 20, 2477-2489.

Calas, G. (1988) Electron Paramagnetic Resonance. Rev. Mineral, 18, 513-571.

Campbell, K.E. Jr.; Frailey, C.D.; Romero-Pittman, L. (2006) The Pan-Amazonian Ucayali Peneplain, late Neogene sedimentation in Amazonia, and the birth of the modern Amazon River system. Palaeogeography, Palaeoclimatology, Palaeoecology, 239, 166-219.

Chauvel, A., Pedro, G. (1978) Genèse de sols beiges (ferrugineux tropicaux lessivés) par transformation des sols rouges (ferrallitiques) de Casamance (Sénégal) modalité de leur propagation. Cah. ORSTOM sér. Pédol., 16 (3), 231-249

Clozel, B., Allard, T., Muller, J.P. (1994) Nature and stability of radiation-induced defects in natural kaolinites : new results and a reappraisal of published works. Clay and Clay Minerals, 42 (6), 657-666.

Cramer, B.S., Toggweiler, J.R., Wright, J.D., Katz, M.E., Miller, K.G. (2009) Ocean overturning since the Late Cretaceous: Inferences from a new benthic formaniniferal isotope compilation. Paleoceanography, 24, 4216

Dall'agnol R., Macambira M.J.B. (1992) Titanita-biotita granitos do Baixo Rio Uaupés, Província Rio Negro, Amazonas. Parte I: Geologia petrografia e geocronologia. Rev. Bras. Geoc, 22, 3-14.

Dequincey, O., Chabaux, F., Clauer, N., Sigmarsson, O., Liewig, N., Leprun, J.C. (2002) Chemical obilizations in laterites: evidence from trace elements and ${ }^{238} \mathrm{U}^{223} \mathrm{U}-{ }^{230} \mathrm{Th}$ disequilibria. Geochimica et Cosmochimica Acta, 66 (7), $1197-1210$.

Do Nascimento, N.R., Bueno, G.T., Fritsch, E., Herbillon, A.J., Allard, T.,Melfi, A.J., Astolfo, R., Boucher, H., Li, Y. (2004) Podzolisation as a deferralitization process. A study of an Acrisol-Podzol sequence de- rived from Paleozoic sandstones in the northern upper Amazon Basin. European Journal of Soil Science, 55, 523538. 
Dubroeucq, D. Volkoff, B. (1988) Evolution des couvertures pédologiques sableuses à podzols géants d'Amazonie, basin du haut Rio Negro. Cah. ORSTOM sér. Pédol., 24 (3), 191-214

Dubroeucq, D. Volkoff, B. (1998) From oxisols to Spodosols and Histosols: evolution of the soil mantles in the Rio Negro basin (Amazonia). Catena, 32, 245-280

Duval, M., (2012) Dose reponse curve of the ESR signal of the Aluminium center in quartz grains extracted from sediment. Ancient TL, 30, 41-49.

FAO Unesco (1998) Soil Map of the world

Farmer, V.C. (1974) The layer silicates. The infrared spectra of minerals, The mineralogical society, 4, 331-363

Fritsch, E., Herbillon, A.J., Jeanroy, E., Pillon, P., Barres, O. (1989) Variations minéralogiques et structurales accompagnant le passage « sols rouges - sols jaunes » dans un bassin versant caractéristique de la zone de contact forêt-savane de l'Afrique occidentale (Booro-Borotou, Côte d'Ivoire). Science Géologiques, bulletins et mémoires, 42 (2), 65-89.

Fritsch, E., Montes-Lauar, C.R., Boulet, R., Melfi, A.J., Balan, E., Magat, P. (2002) Lateritic and redoximorphic features in fractured soils and sediments of the Manaus plateaus, Brazil. European Journal of Soil Science, 53, 203-218.

Fritsch, E., Morin, G., Bedidi, A., Bonnin, D., Balan, E., Caquineau, S. \& Calas, G. (2005) Transformation of haematite and Al-poor goethite to Al-rich goethite and associated yellowing in a ferralitic clay soil profile of the middle Amazon Basin (Manaus, Brazil). European Journal of Soil Science, 56, 575-588.

Fritsch, E., Balan, E., Régina Do Nascimento, N., Allard, T., Bardy, M., Bueno, G., Derenne, S., Melfi, A.J. \& Calas, G. (2011) Deciphering the weathering processes using environmental mineralogy and geochemistry: Towards an integrated model of laterite and podzol genesis in the Upper Amazon Basin. Comptes Rendus Geoscience, 343, 188-198.

Furian, S., Barbiero, L., Boulet, R., Curmi, P., Grimaldi, M., Grimaldi, C. (2001) Distribution and Dynamic of Gibbsite and Kaolinite in an Oxisol of Serra do Mar, southeastern Brazil. Geoderma, 106, 83-100.

Gaillardet, J., Dupre, B., Allegre, C.J., Négrel, P. (1997) Chemical and physical denudation in the Amazon River Basin. Chemical Geology, 142 (3-4), 141-173.

Gaite, J.M., Ermakoff, P. Allard, T., Muller, J.P. (1997) Paramagnetic $\mathrm{Fe}^{3+}$ : A sensitive probe for disorder in kaolinite. Clay and clay minerals, 45, 496-505.

Gehring, A.U., Fry, I.V., Luster, J. Sposito, G. (1993), The chemical form of Vanadium (IV) in Kaolinite. Clay Minerals, 41 (6), 662-667.

Giral-Kacmarcík, S., Savin, S.M., Nahon, D.B., Girard, J.-P., Lucas, Y. \& Abel, L.J. (1998) Oxygen isotope geochemistry of kaolinite in laterite-forming processes, Manaus, Amazonas, Brazil. Geochimica et cosmochimica acta, 62, 1865-1879.

Girard, J.-P., Freyssinet, P. \& Morillon, A.-C. (2002) Oxygen isotope study of Cayenne duricrust paleosurfaces: implications for past climate and laterization processes over French Guiana. Chemical Geology, 191, 329-343.

Hall, P.L. (1980) The application of electronic paramagnetic resonance spectroscopy to studies of clay minerals: I. Isomorphous substitutions and external surface properties. Clay Minerals, 15, 321-335.

Haq, B. U., Hardenbol, Vail, J.P. (1987) Chronology of Fluctuating Sea Levels Since the Triassic. Science, 235, 1156-1166.

Harris, S.E., Mix, A.C. (1999) Pleistocene precipitation balance in the Amazon basin recorded in deep sea sediments. Quaternary Research, 51, 14-26.

Haywood, A.M., Dowsett, H.J., Dolan, A.M. (2016) Integrating geological archives and climate models for the mid-Pliocene warm period. Nature Communication, 7: 10646, 2-14.

Hennig, G.J., Grün, R. (1983) ESR dating in quaternary geology. Quaternary Science Review, 2, 157-238.

Hermann, L., Anongrak, N., Zarei, M., Schuler, U., Spohrer, K. (2007) Factors and processes of gibbsite formation in Northern Thailand, Catena, 71, 279-291.

Hoorn, C., Wesselingh, F.P., ter Steege, H., Bermudez, M.A, Mora, A., Sevink, J., Sanmartin, I., SanchezMeseguer, A., Anderson, C.L., Figueiredo, J.P., Jaramillo, C., Riff, D., Negri, F.R., Hooghiesmstra, H., Lundberg, J., Stadler, T., Särkinen, T., Antonelli, A. (2010) Amazonia Through Time: Andean Uplift, Climate Change, Landscape Evolution and Biodiversity. Science, 330, 927.

Hovan, S. (1995) Late Cenozoic atmospheric circulation intensity and climate history recorded in ealian deposits in the eastern equatorial Pacific. Proceeding of Ocean Drilling Program, 138, 615-625.

Insel, N., Poulsen, C.J., Ehlers, T.A. (2009) Influence of the Andes Mountains on South American moisture transport, convection and precipitation. Clim. Dyn., 35 (7-8), 1477-1492.

Ishida, D.A., Montes, C.R., Lucas, Y., Pereira, O.J.R., Merdy, P., Melfi, A.J. (2014) Genetic relationships between ferralsols, podzols and white kaolin in Amazonia. European Journal of Soil Science, 65, 706-717.

Karas, C., Nürnberg, D., Bahr, A., Groeneveld, J., Herrle, J.O., Tiedemann, R., deMenocal, P. (2017). Pliocene oceanic seaways and global climate. Sci. Rep., 7, $\mathbf{3 9 8 4 2}$

King, L.C. (1956) Geomorfologia do Brazil Oriental. Rev. Bras. Geografia. 18 (2), 146-265 
Kleeman, J.D., Lovering, J.F. (1967) Uranium distribution in rocks by fission-track registration in lexan plastic. Science, 156 (3774), 512-513.

Langmuir, D., Herman, J.S. (1980) The mobility of thorium in natural waters at low temperatures. Geochimica et Cosmochimica Acta, 44, 1753-1766.

Leonardi, F.A.; Ladeira, F.S.B. (2011) Santos, M. Paleosurfaces and Bauxite Profiles in the Poços de Caldas Plateau, São Paulo/Minas Gerais, Brazil. Geociências, 30 (2),147-160.

Linton, D.L. (1955) The problem of tors. The Geographical Journal, 121(4), 470-481

Lucas, Y.,Boulet, R. et Veillon, L. 1987. Systèmes sols ferralitiques - podzols en région amazonienne. Podzols et Podzolisation, Righi, D. et Chauvel, A., éd. INRA, Paris, 53-65.

Lucas, Y., Nahon, D., Cornu, S., Eyrolle, F. (1996) Genèse et fonctionnement des sols en milieu équatorial. Compte Rendus de l'Académie des Sciences, 322, 1-16.

Lucas, Y., Montes, C.R., Mounier, S., Loustau Cazalet, M., Ishida, D., Achard, R., Garnier, C., Coulomb, B., Melfi, A.J. (2012) Biogeochemistry of an Amazonian podzol-ferralsols soil system with white kaolin. Biogeosciences, 9, 3705-3720.

Maignien, R. (1961) Le passage des sols ferrugineux aux sols ferrallitiques dans les régions sud-ouest du Sénégal (République du Sénégal). Sols africains, 6 (2 et 3), 113-228

Mathian, M., Aufort, J., Braun, J.J., Riotte, J., Selo, M., Balan, E., Fritsch, E., Bhattacharya, S., Allard, T. (2018) EPR dating of laterites from Western Ghats (India): a record of Asiatic monsoon strengthening. Submitted in Gondwana Research.

Mehra, O.P., Jackson, M.L. (1960) Iron oxide removal from soils and clays by a dithionite-citrate system buffered with sodium bicarbonate. Clays and Clay minerals, 7, 317-327.

Melfi, A., Fritsch, E., Boulet, R., Seyler, F., Carvalho, A., Magat, P. (1996) Magat, P. In Distribuição dos solos nas paisagens lateríticas da amazônia. Elaboração de um modelo conceitual ilustrando a evolução hydro-biogeoquímica destas paisagens, XIII Congresso Latino Americano de Ciência do solo, Águas de Lindoia, Brasil

Miller, K.G., Kominzs, M.A., Browning, J.V., Wright, J.D., Mountain, G.S., Katz, M.E., Sugarman, P.J., Cram, B.S., Christie-Blick, N., Pekar, S.F. (2005) The Phanerozoic Record of Global Sea-Level Change. Science, 310, 1293-1298.

Monteiro, H.S., Vasconcelos, P.M., Farley, K.A., Spier, C.A., Mello, C.L. (2014) (U-Th)/He geochronology of goethite and the origin and evolution of cangas. Geochimica Cosmochimica Acta, 131, 267-289.

Montes, C., Cardona, A., Jaramillo, C., Pardo, A., Silva, J.C., Valencia, V., Ayala, C., Pérez-Angel, L.C., Rofriguez-Parra, L.A., Ramirez, V., Nino, H. (2015) Middle Miocene closure of the Central American Seaway. Science, 348, 226-229.

Mora, A., Baby, P., Roddaz, M., Parra, M., Brusset, S., Hermoza, W., Espurt, N. (2010) Tectonic history of the Andes and Sub-Andean zones: implications for the development of the Amazon drainage basin. Amazonia, Landscape and Species Evolution: A look into the Past., 1 st edition. Edited by C. Hoorn and F.P. Wesselingh, Chapter four.

Mosser, C., Boudeulle, M., Weber, F, Pacquet, A. (1996) Ferriferrous and vanadiferous kaolinites from the hydrothermal alteration halo of the Cigar Lake uranium deposit (Canada). Clay Minerals, 32, 291-299.

Muller, J.P., Calas, G. (1993) Genetic significance of paramagnetic centers in kaolinites. Kaolin Genesis and Utilization, HH. Murray, W. Bundy and C. Harvey, eds, The Clay Minerals Society, Boulder, Colorado, 261289.

Nahon, D. (2003) Altérations dans la zone tropicale. Signification à travers les mécanismes anciens et/ou encore actuels. C.R. Geosciences, 335, 1109-1119.

Oczkowski, H.L., Prezegietka, K.R., Lankauf, K.R., Szmanda, J.B. (2000) Gamma spectrometry in thermoluminescence dating. Geochronometria, 18, 57-62

Ollier et al., 1988

Premović P.I., Ilić B.S. \& Djordjević D.M. (2011) A new method for determining the concentration of vanadyl ions in clays. Geol.Carpathica, 62, 181-186.

Price, P.B., Walker, R.M. (1963) Fossil tracks of charged particles in mica and the age of minerals. Journal of geophysical research, 68 (16), 4847-4862.

Projeto Radam (or Radam Brazil) 1972-78. Levantamento de Recursos Naturais. Ministerio das Minas e Energia, Departamento Nacional da Producxa o Mineral, Rio de Janeiro, Brazil.

Richter, D.deB.., Yaalon, D.H. (2012) “The Changing Model of Soil” Revisited. Soil Science Society of America Journal, 76, 766-778.

Rossetti, D.d.F., de Toledo, P.M., Goes, A.M. (2005) New geological framework for Western Amazonia (Brazil) and implications for biogeography and evolution. Quaternary Reseach, 63, 78-89.

Rozanski, K. Araguas-Aruaguas, L., Plata, B.A., Franken, W., Tancredi, A.C., Tundis Vital, A. (1991) Downward movement of soil moisture in the central Amazon region traced by means of hydrogen isotopes. Proc. International Symposium on the use of stable isotopes in Plant nutrition, soil fertility and environmental study, IAEA-SM-313. 
Santos J.O.S, Hartmann L.A., Gaudette H.E., Groves D.I., Mc Naughton N.J., Fletcher I.R. (2000) A new understanding of the provinces of the Amazon Craton based on integration of field mapping and U-Pb and SmNd geochronology. Gondwana Research, 3 (4), 453-488

Sélo, M. (1983) La fission nucléaire et sa signification en géochronomogie, paléothermométrie et géochimie. Applications à l'étude particulière des basalts océaniques. Thèse d'état, Université Paris VI.

Sepulchre, P., Sloa, L.C., Fluteau, F. (2010). Climate variation in Amazonia during the Neogene and the Quaternary. Amazonia, Landscape and Species Evolution: A look into the Past., 1 st edition. Edited by C. Hoorn and F.P. Wesselingh, Chapter thirteen.

Schwertmann, U. (1993) Relations between iron oxides, soil color and soil formation. Soil color, J.M. Bogham and E.J. Ciolkosz, editors, SSSA, Madison, WI, 51-69

Shvartsev, S.L. (2012) The Internal Evolution of the Water-Rock Geological System. Herald of the Russian Academy of Soil Sciences, 82, 134-142.

Shuster, D.L., Vasconcelos, P.M., Heim, J.A., Farley, K.A. (2005) Weathering geochronology by (U-Th)/He dating of goethite. Geochimica et Cosmochimica Acta, 69(3), 659-673.

Taitson Bueno, G. (2009) Podzolização das lateritas da alta bacia amazônica: Mecanismos, características mineralógicas dos produtos neoformados e relações com a evolução da paisagem. PhD of Universidade Estadual Paulista Júlio de Mesquita Filho, UNESP, Brasil.

Taitson Bueno, G., Soares Cherem, L.F., Toni, F., Silva Guimaräes, F., Bayer, M. (2019) Amazonia. The

physical Geography of Brazil, Geography of the physical environment, eds A.A.R. Salgado et al.

Tardy, Y., Kobilsek, B., Paquet, H. (1991) Mineralogical composition and geographical distribution of African and Brazilian periatlantic laterites. The influence of continental drift and tropical paleoclimate during the past 150 million years and implications for India and Australia, Journal of African Earth Sciences, 12, 283-295

Taylor, R.G., Howard, K.W.F. (1999) Lithological evidence for the evolution of weathered mantles in Uganda by tectonically controlled cycles of deep weathering and stripping. Catena, 35, 65-94.

Théveniaut, H., Freyssinet, P. (1999) Paleomagnetism applied to lateritic profiles to assess saprolite and duricrust formation processes: the example of Mont Baduel profile (French Guiana). Palaeogeogr., Palaeoclim., Palaeoecol, 148 (4), 209-231.

Théveniaut, H., Freyssinet, P. (2002) Timing of lateritization on the Guiana Shield: synthesis of paleomagnetic results from French Guiana and Suriname. Palaeogeogr., Palaeoclim., Palaeoecol, 178 (1-2), 91-117.

Retallack, G.J. (2010) Lateritization and bauxitization events. Economic Geology, 105, 655-667.

Russel, J.D., Fraser, A.R. (1994) Infrared methods. Clay mineralogy: Spectroscopic and Chemical Determinative methods, London: Chapman et al., 11-67

Vasconcelos, P.M., Renne, P.R., Brimhall, G.H., Becker, T.A. (1994) Direct dating of weathering phenomena by 40Ar/39Ar and K-Ar analysis of supergene K-Mn oxides. Geochimica et Cosmochimica Acta, 6, 1635-1665.

Vasconcelos, P.M. (1999) K-Ar AND ${ }^{40} \mathrm{Ar} /{ }^{39} \mathrm{Ar}$ Geochronology of weathering processes. Annual Review of Earth and Planetary Science, 27, 183-229.

Vasconcelos, P.M., Reich, M., Suster, D.L., (2015). The paleoclimatic signatures of supergene metal deposits. Elements, 11, 317-322.

Vonhof, H.B., Kaandorp, R.J.G. (2010). Climate variation in Amazonia during the Neogene and the Quaternary. Amazonia, Landscape and Species Evolution: A look into the Past., 1 st edition. Edited by C. Hoorn and F.P. Wesselingh, Chapter twelve.

Yoo, K., Mudd, S.M. (2008). Toward process-based modeling of geochemical soil formation across diverse landforms: A new mathematical framework. Geoderma, 146, 248-260.

Zachos, J., Pagani, M, Sloan, L., Thomas, E., Billups, K. (2001) Trends, Rhythms, and Aberrations in Global

Climate 65 Ma to Present. Science, 292, 686-693.

\section{Figures captions:}

Fig. 1: A: Soil map of Amazonia (modified from Taitson et al., 2019) and approximative location of the region study B: Soil map of the Rio Curicuriari basin, with the several soils transitions linked to the topography. C: Schematic geomorphologic model of local soil landform dynamic with their three major weathering and erosion processes: podzolisation (white arrow), iron and clay translocation (Acrisol formation, grey arrow) and river network incision (dark arrow). The Ib and Ic sequence are characteristic of low and middle Rio Negro catchment and IIb and IIc of the Upper Rio Negro catchment. The Rio Curicuriari studied transect is characteristic of the Ib scheme (From Bueno Taitson, 2009). 
Fig. 2: Scheme of the Caju (CA)-Cobra (CO2) transect, with the lateral transformation of Acrisol into Podzol and the Ferralsol/Acrisol transition. Two profiles, Caju and Cobra, were selected to represent local Ferralsol and Acrisol. Twelve samples were sampled from CA and CO2.

Fig. 3: A: XRD pattern of CO2 samples, normalised to the maximal intensity of the 7.2A peak of the kaolinite. B: XRD pattern of the CA samples, normalised to the maximal intensity of the 4.95 peak of gibbsite. The CO2 55 , CA 380, and CA 485 sample XRD has not been recorded due to the lack of sample. With: Kln : Kaolinite; Gbst: Gibbsite; Qtz: Quatz; Gte: Goethite; Hm: Hematite; Ant: Anatase (Ti Oxide); Chl: Chlorite; Sm: Smectite.

1169

Fig. 4: A: EPR spectra of CO2 clay fractions. B: EPR spectra of CA clay fractions CA 280, 360 and 380 excluded due to due to their remaining magnetic minerals content influence in the $\mathrm{g}=4$ zone. $\mathrm{C}$ : Zoom on the stretching zone of the CO2 clay fraction FTIR spectra. The spectra are normalized considering the $3620 \mathrm{~cm}^{-1}$ band attributed to the kaolinite. The CO2 55 sample spectrum has not been recorded due to the lack of sample. D: Zoom on the stretching zone of the CA clay fraction FTIR spectra, CA 360 and 380 excluded due to the number of samples. The spectra are normalised considering the $3526 \mathrm{~cm}^{-1}$ band attributed to gibbsite.

Fig. 5: A: Zoom of the $\mathrm{g}=2$ zone of the $\mathrm{CO} 2$ clay fraction EPR spectra. B: Zoom of the $\mathrm{g}=2$ zone of the CA clay fraction EPR spectra. With TIs: the $g=2.006$ normalized intensity of the considered sample and $\mathrm{TI}_{\mathrm{dim}}:$ the $\mathrm{g}=2.007$ normalized intensity of the dimex EPR signal, $\mathrm{I}_{\mathrm{zdim}}$ : the normalized intensity of the $1.881 \mathrm{~g}$ signal of the EPR dimex spectra and $\mathrm{I}_{\mathrm{zs}}$ : the normalized intensity of the 1.881 signal of the sample EPR spectra

Fig. 6: A: EPR spectra in the $\mathrm{g}=2$ zone for irradiated CA samples, corresponding dosimetry curves and resulting paleodoses with a: CA 84, b: CA 200, c: CA 440, d: CA 480. The $10^{12}$ irradiation amplitude has not been considered as it appears aberrant. B: EPR spectra in the $\mathrm{g}=2$ zone for irradiated CO2 samples, corresponding dosimetry curves and resulting paleodoses with samples. With a: CO2 45, b: CO2 200, c: CO2 280, d: CO2 450).

Fig. 7 A: $U$ and Th comparison for both parts of the two studied profiles with sa: Saprolite (C horizon) and ss: soil solum. B: Dose rate trend with depth of both profiles. The dash line is the soil solum and saprolite depth transition, with red square the Cajou (CA) sample (Ferralsol) and with black points the Cobra (CO2) samples (Acrisol).

Fig. 8: Kaolinites ages distribution over the Caju-Cobra transect.

Fig.9: Paleodose vs Dose rate plot of the studied samples, the open symbols are corresponding to the samples with an estimated paleodose. Three preferential periods of weathering can be identified: a Miocene-Pliocene period (63.6 Ma), a Pleistocene period (2.5-1.5 Ma) and a Quaternary period (1 Ma to Actual).

Fig.10: Updated schematic geomorphologic model of Curicuriari soil landform dynamic based on the local acrisol and ferralsol chronology. 
Tables captions:

Table 1: $\mathrm{CA}$ and $\mathrm{CO} 2$ horizon description and samples location. The samples noted with an * are the one used for

1204 artificial irradiation and have been investigated using fission tracks mapping methodology.

1205

1206

1207

1208

1209

1210

1211

1212

1213

1214

1215

Table 2: Data table for the Caju (CA) profile and resulting calculated ages. The non-bold values are estimated ages.

Table 3: Data table for the Cobra (CO2) profile and resulting calculated ages. The non-bold values are estimated ages.

Table 4: Data table of the ${ }^{238} \mathrm{U},{ }^{222} \mathrm{Rn},{ }^{226} \mathrm{Ra}$ and ${ }^{232} \mathrm{Th}$ activity obtained by gamma spectroscopy. Ratio between the two activity have been performed to assess the equilibrium of the decay chain. 
A

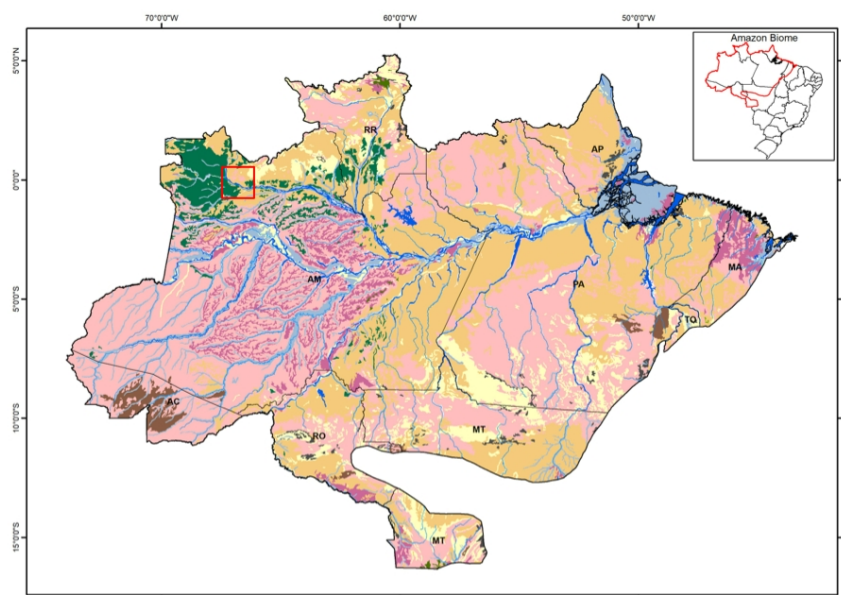

\section{LEGEND}

5 Water bodies $\sim$ Drainage network

\section{Soil Types (FAO, 1998)}

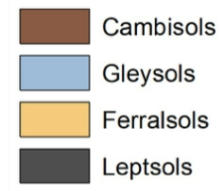

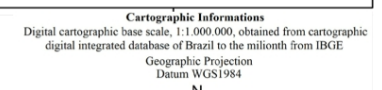
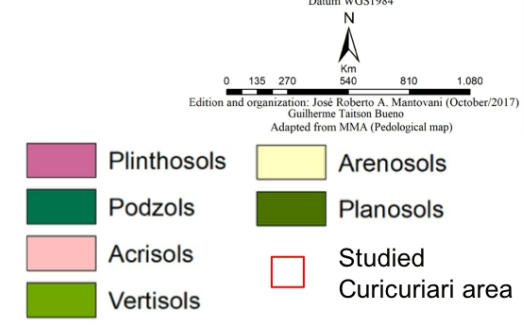

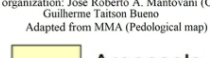

Arenosols

Planosols

Studied Curicuriari area
B

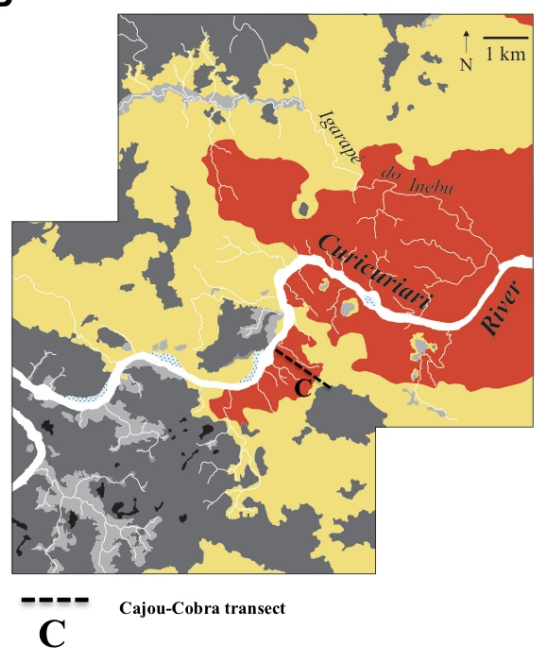

White sand bars and rock outcrops

Incised plateauedges, with red to yellow Ferral sols (forest)

$\square$ Slightly incised plateaux with yellow Acrisols (forest)

Inundated plain and depressions with seasonally waterlogged Podzols

Depression centres with overflooded Podzols (Campina)

Incised plain with better-drained Podzols, (Caatinga and riparian
forest) $\square$ Bleached saprolito

$\square$ Reddish saprolite

\section{C}

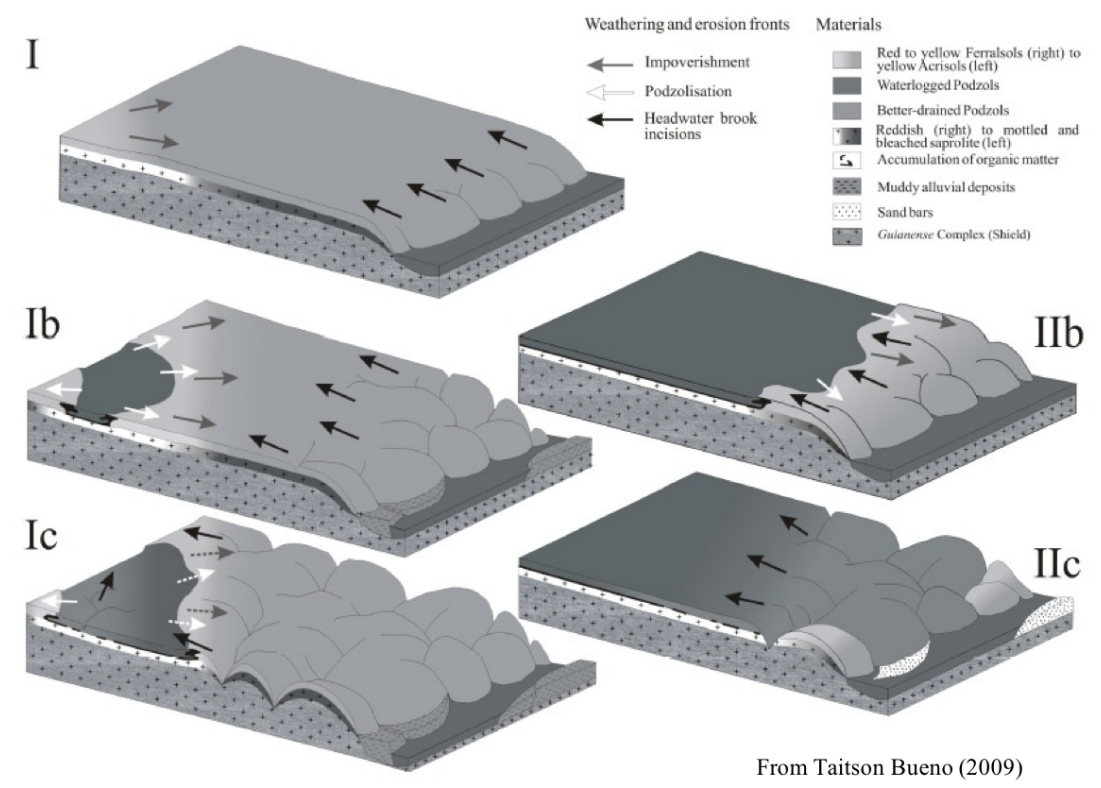




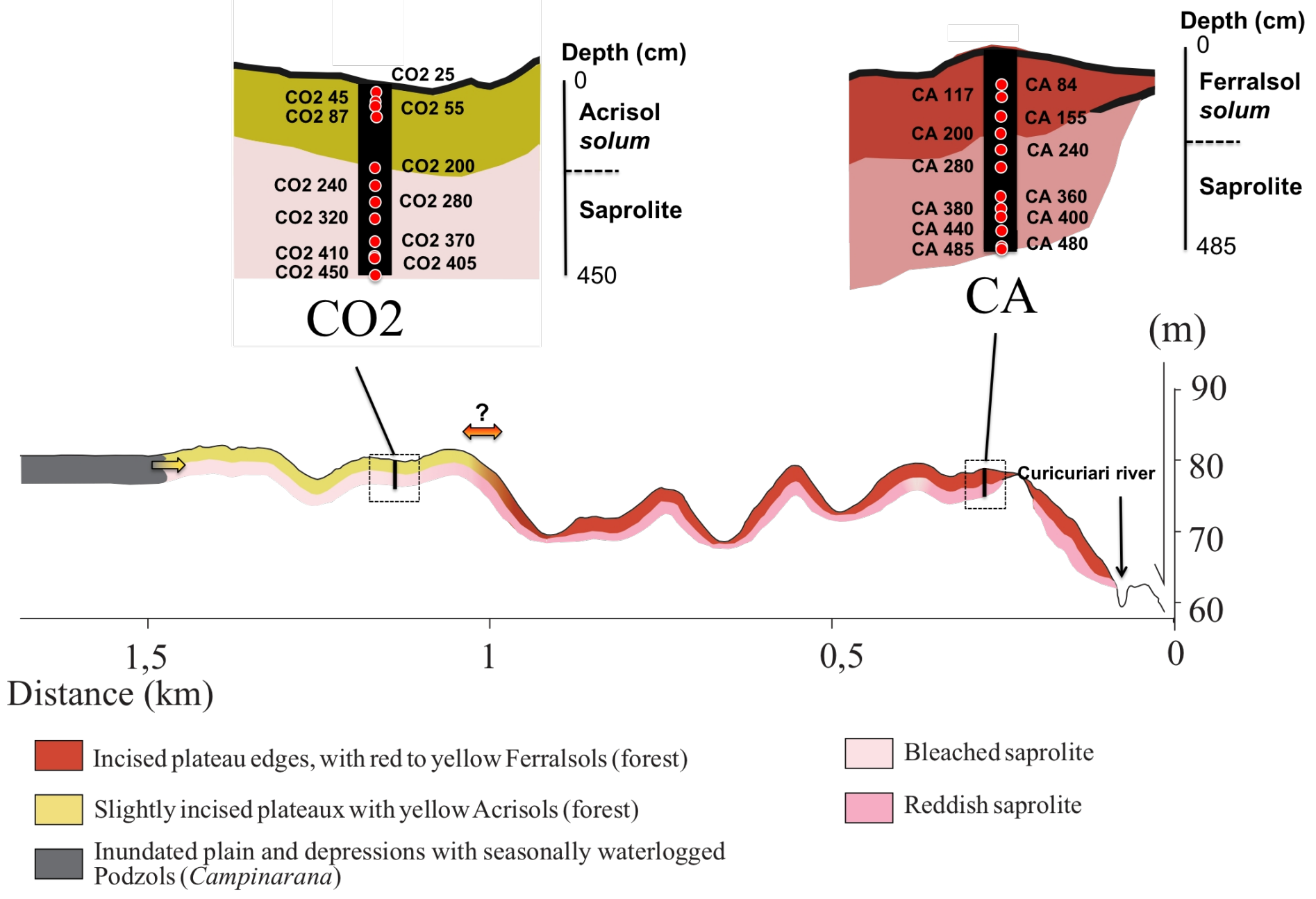



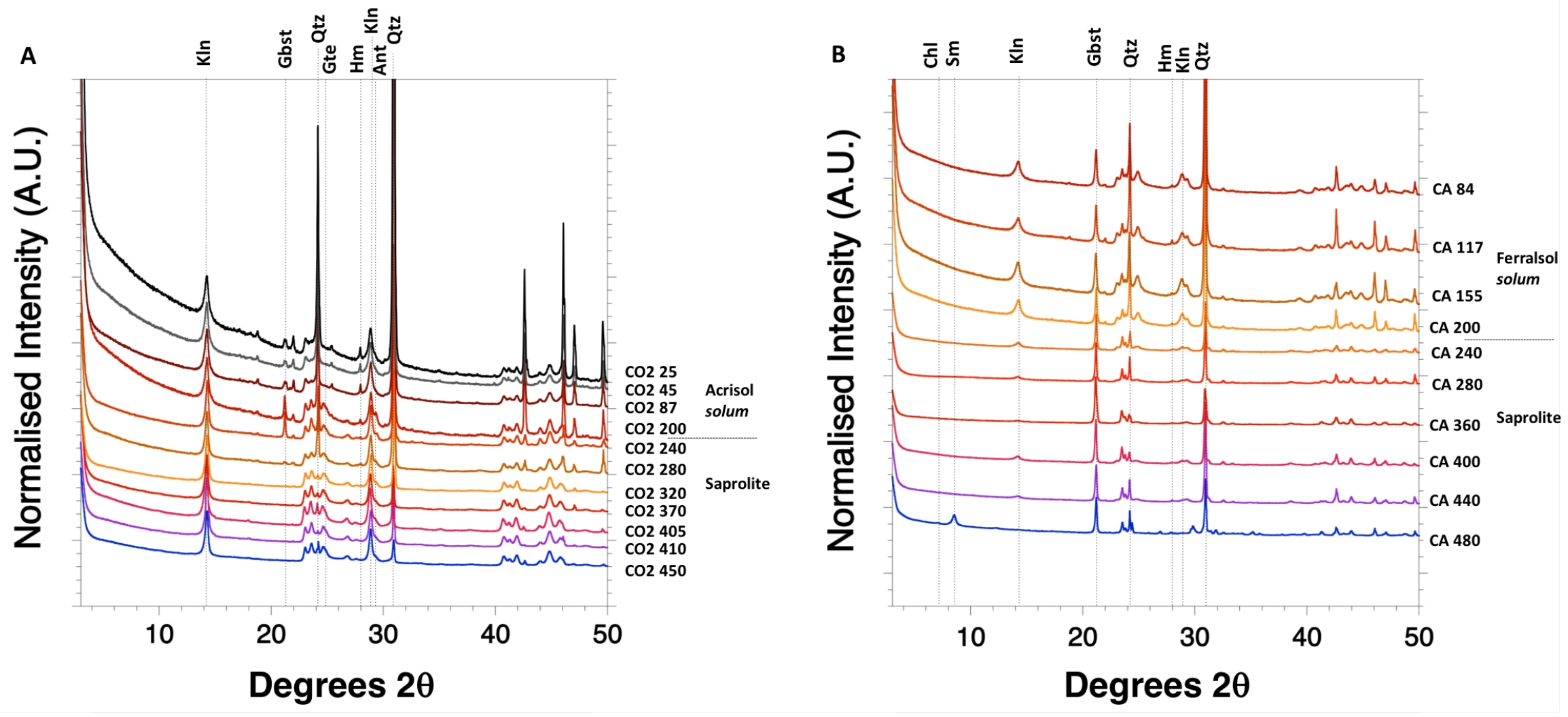

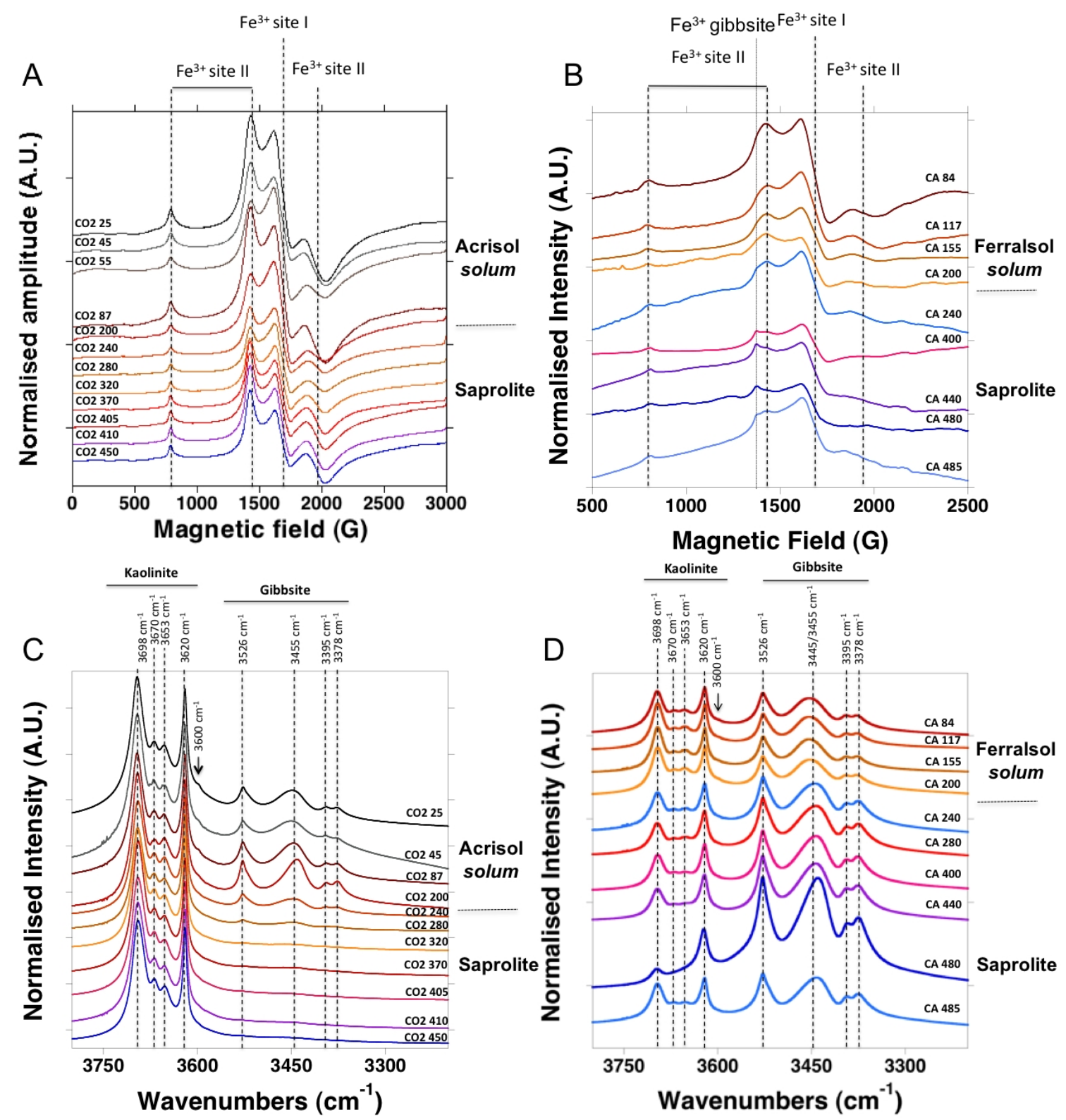

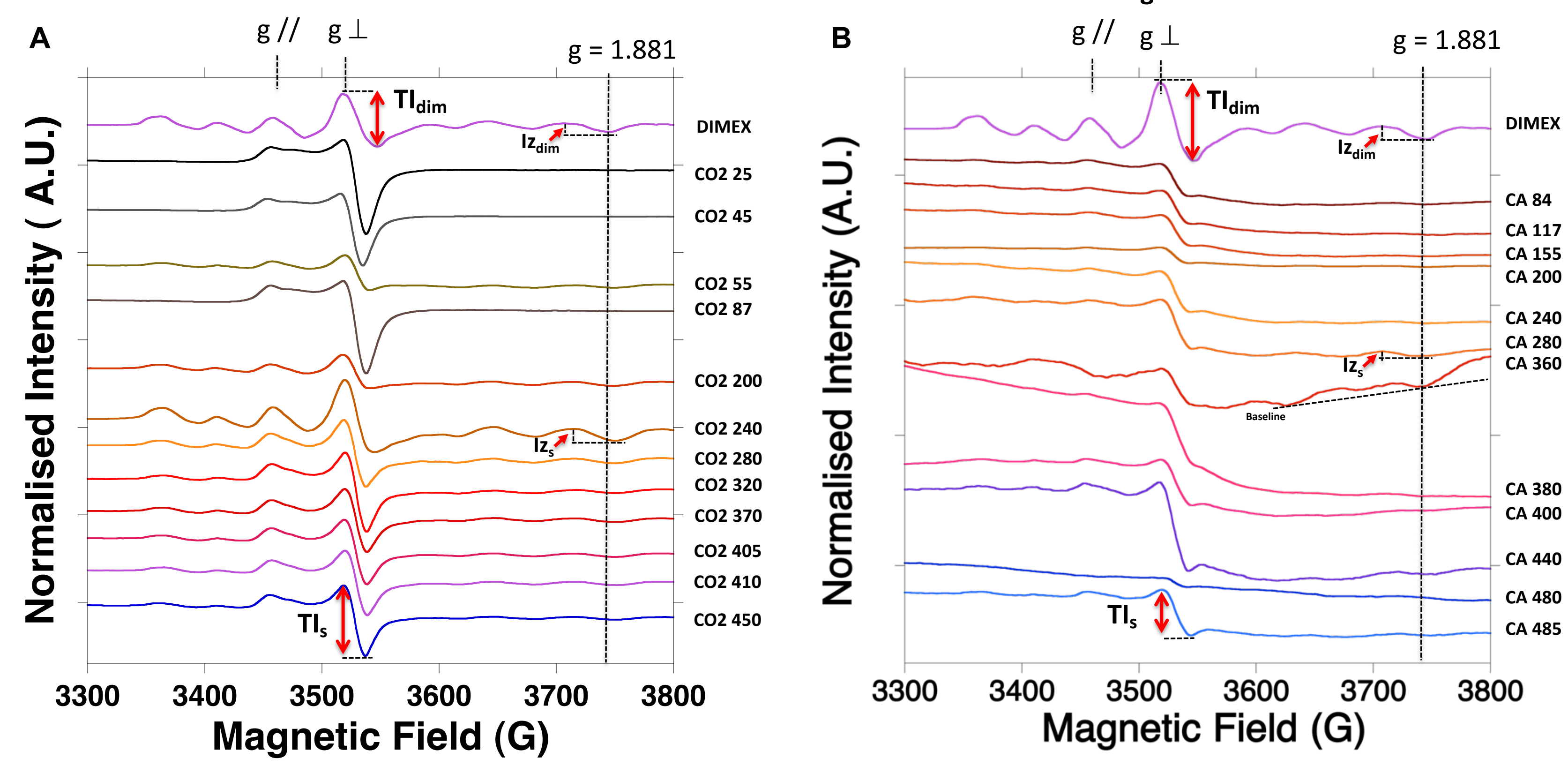
A
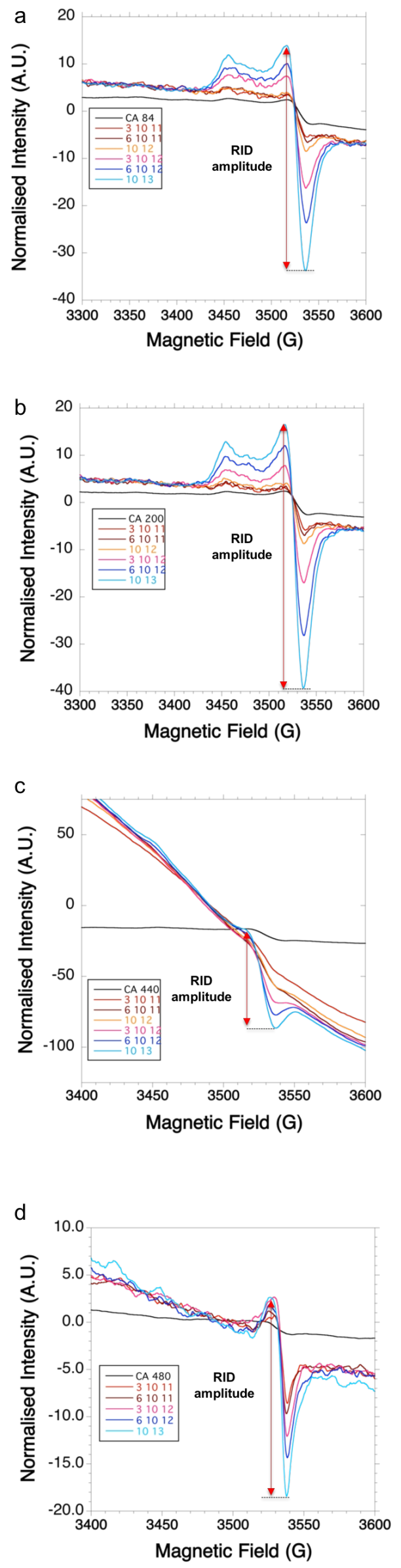

CA 84

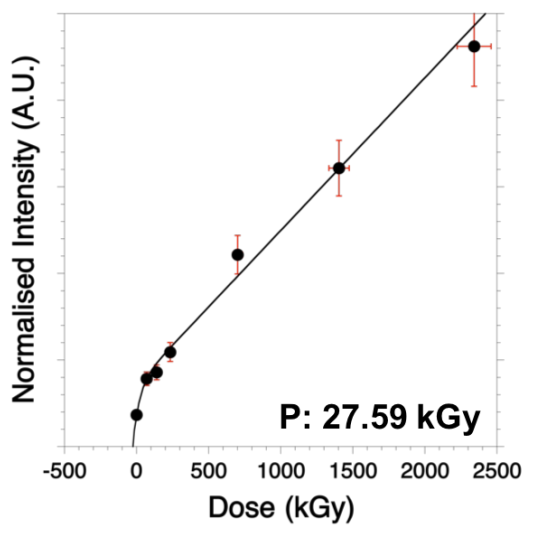

CA 200

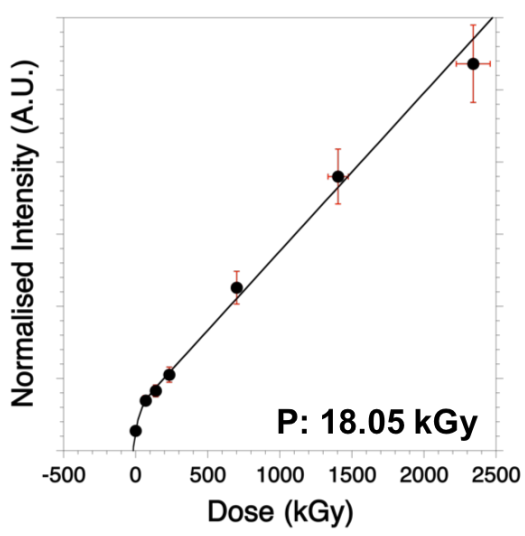

CA 440

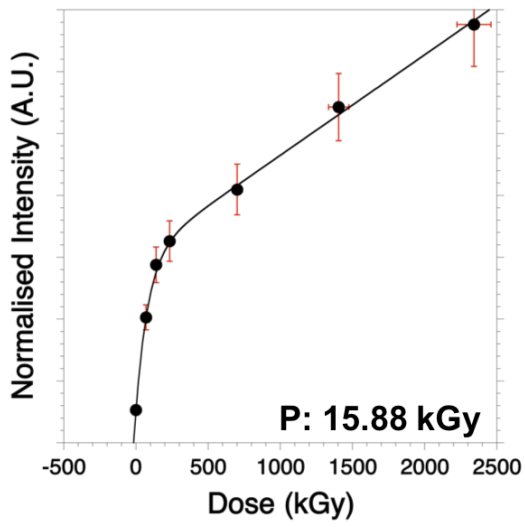

CA 480

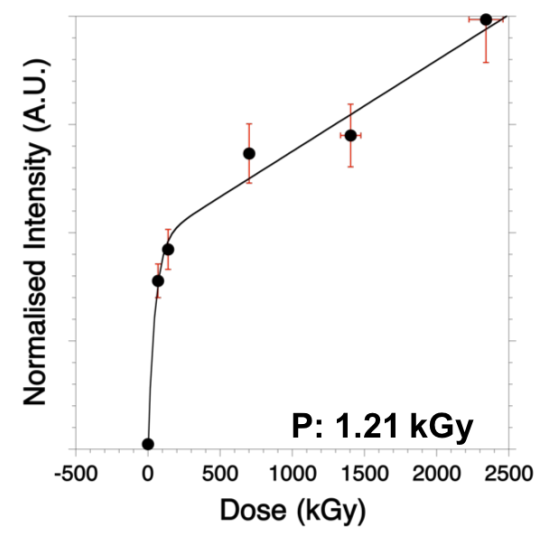



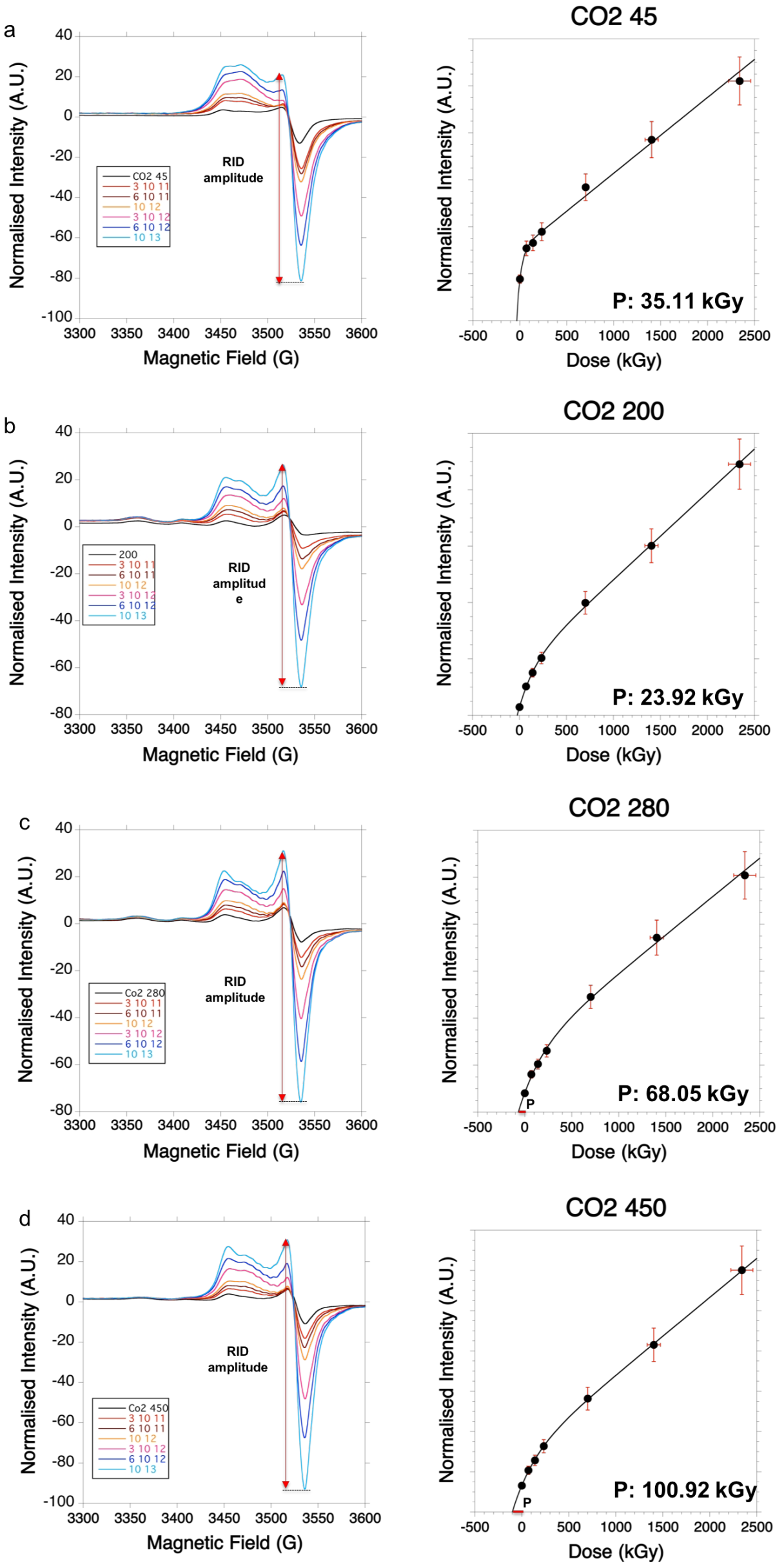
A

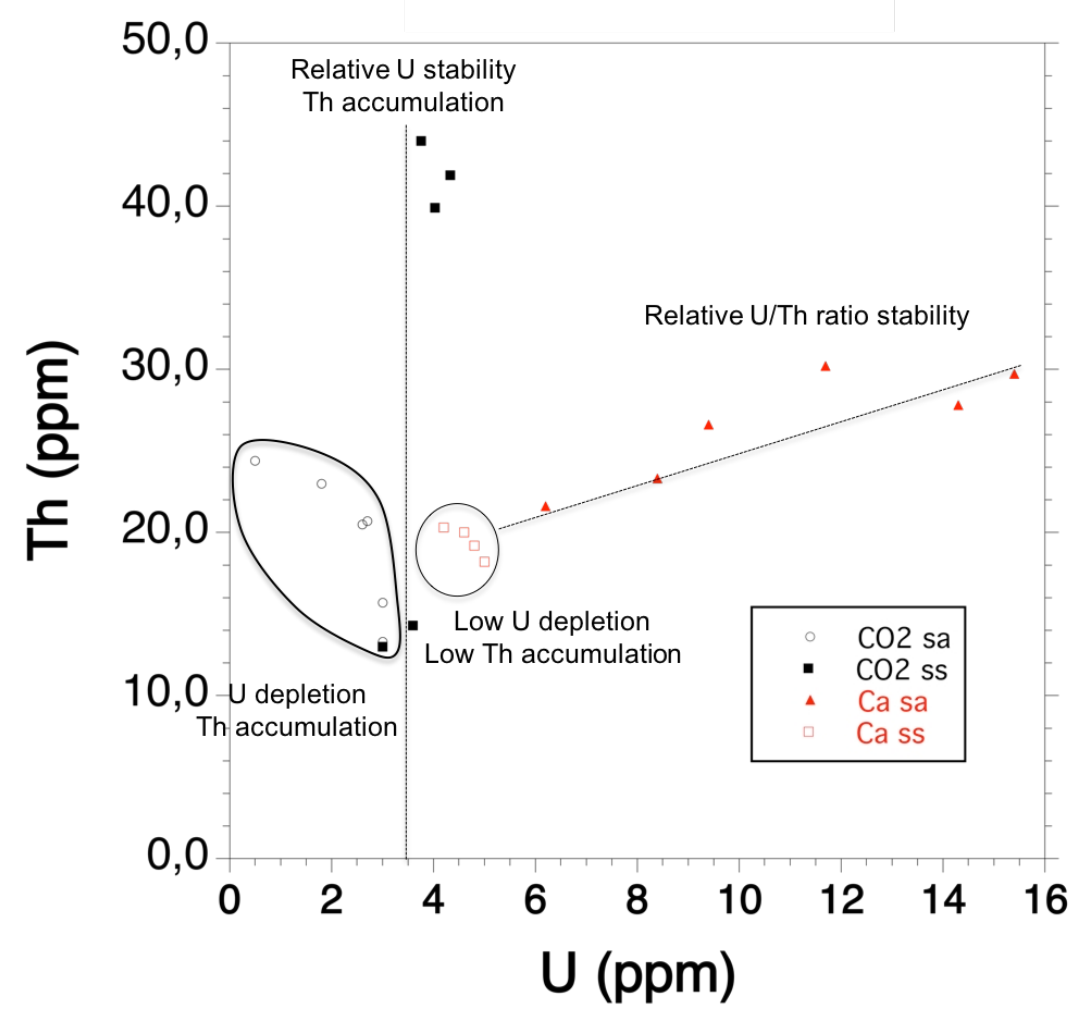

B

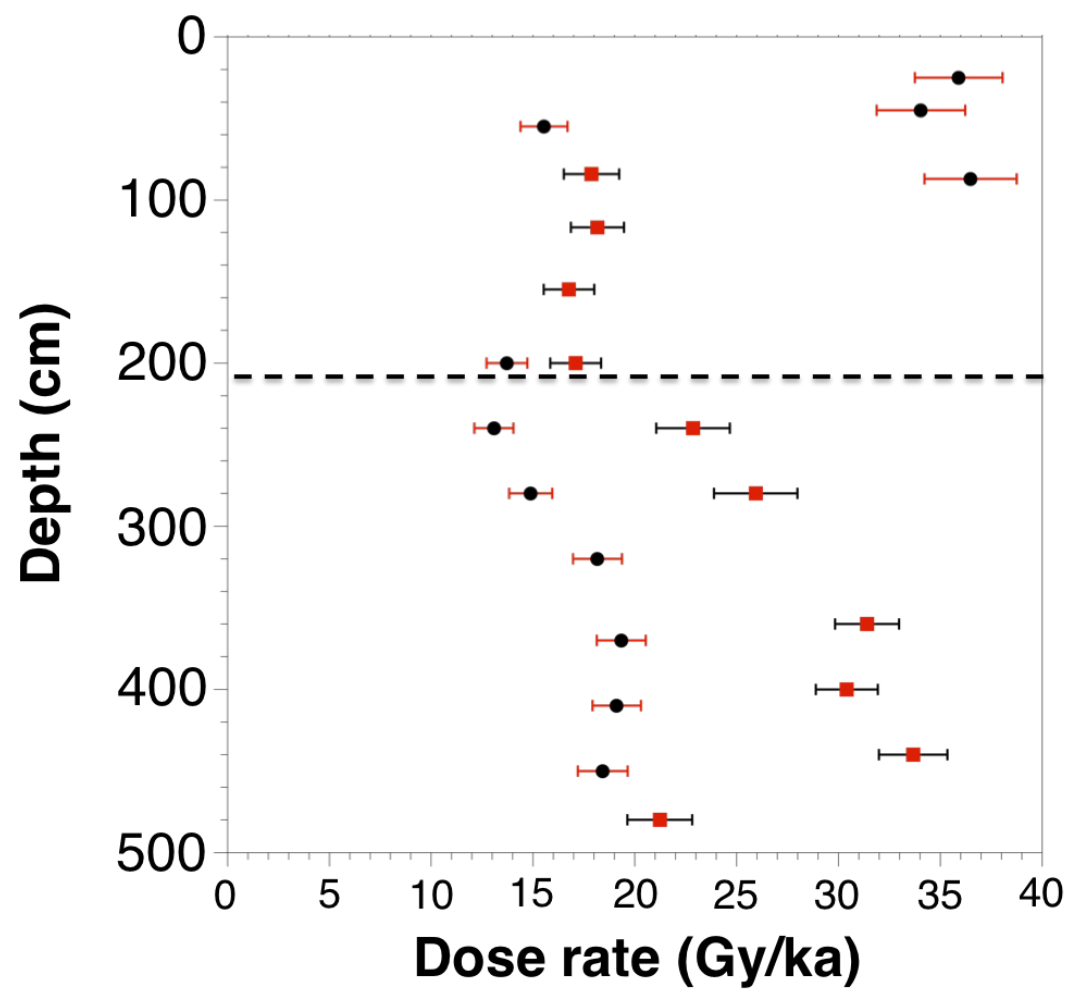




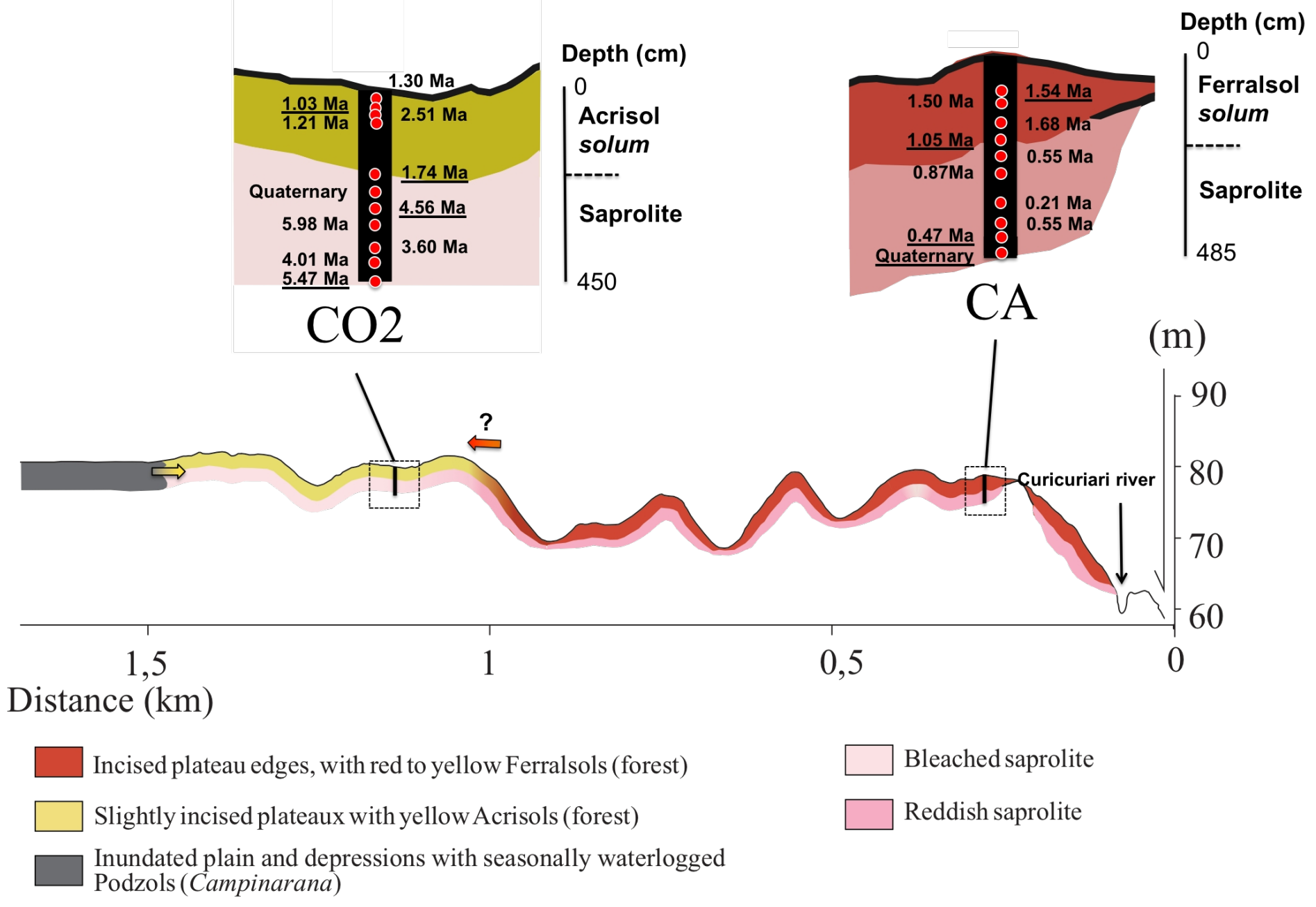




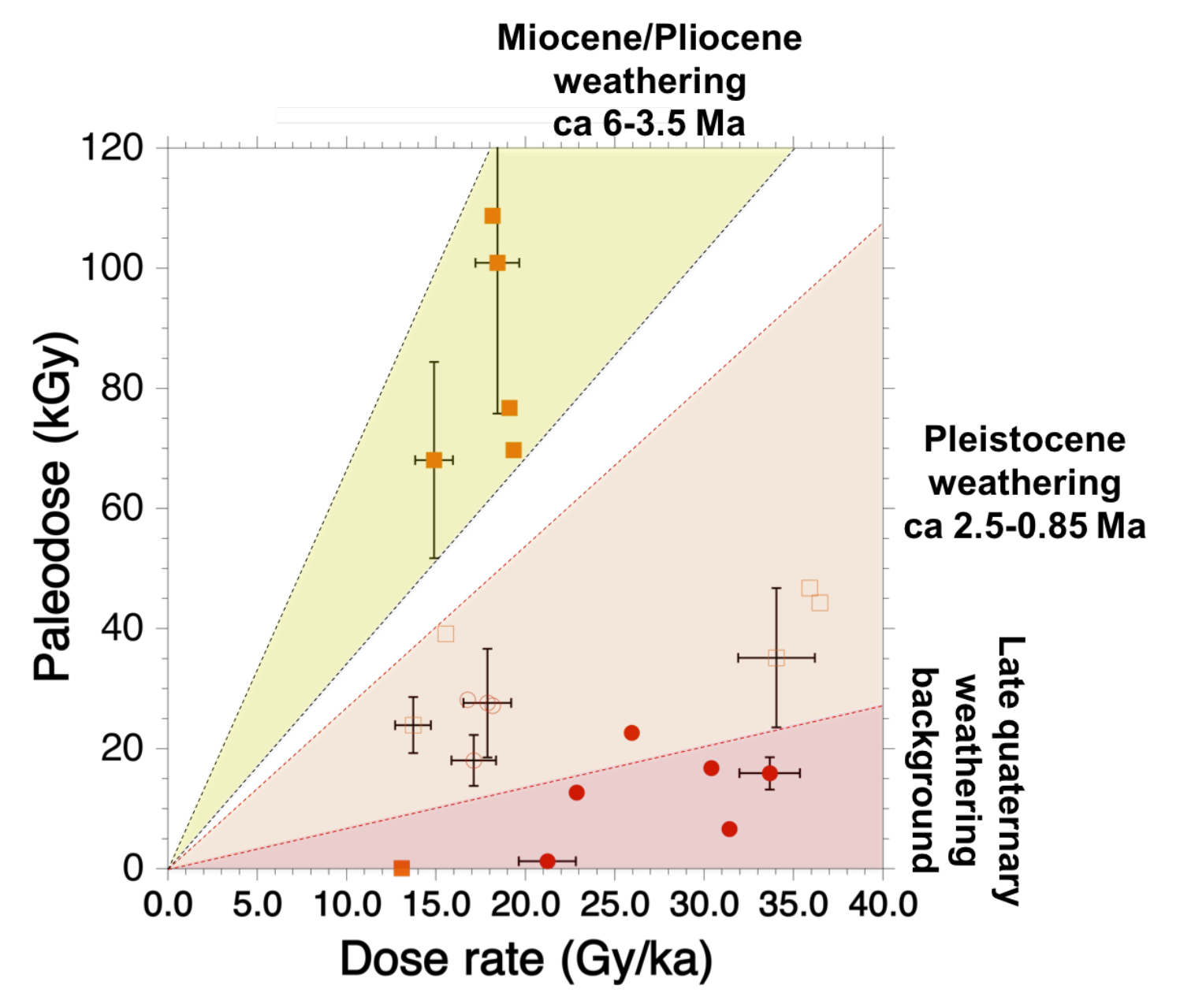

Acrisol (CO2) solum samples

Acrisol (CO2) saprolite samples
Ferralsol (CA) solum samples

Ferralsol (CA) saprolite samples 
I. Formation of an initial Ferralsol $(>6 \mathrm{Ma})$

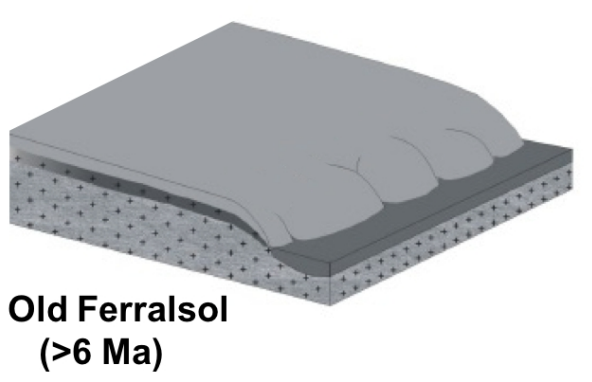

(>6 Ma)
III. Quaternary incision and weathering reactivation:
A quaternary Ferralsol formed in parallal
to the plateau incision

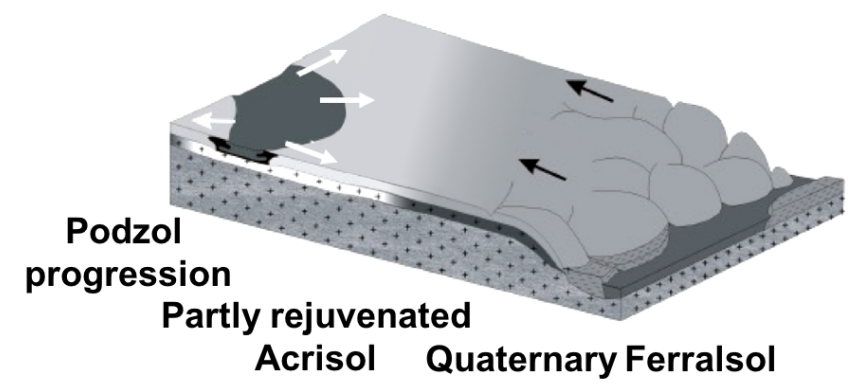

Materials

Red to yellow Ferralsols (right) to

Better-drained Podzols

Reddish (right) to mottled and
bleached saprolite (left)

$\rightarrow$ Accumulation of organic matter

Muddy alluvial deposits

Sand bars yellow Acrisols (left)

Waterlogged Podzols

Guianense Complex (Shield)
4 Impoverishment

$\longrightarrow$ Podzolisation $\longleftarrow$ Headwater brook

\begin{abstract}
(>6 Ma)
A quaternary Ferralsol formed in parallal
to the plateau incision
(>6 Ma)
quaternary Ferralsol formed in parallal
to the plateau incision
\end{abstract}

\section{Weathering and erosion fronts}

II. Late Miocene/Pleistocene weathering: Impoverishment of the Ferralsol and its progressive total transformation into a younger Acrisol

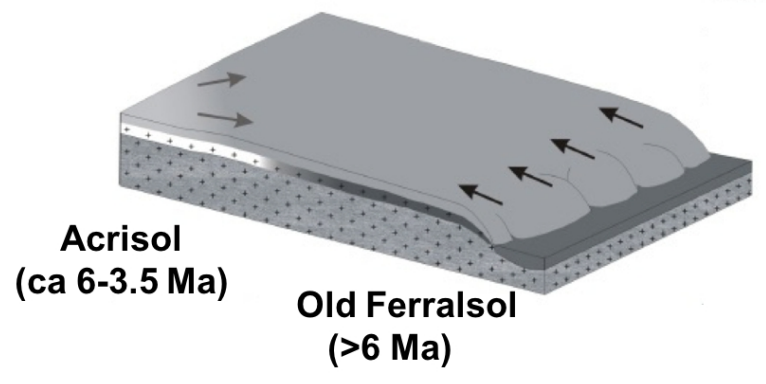

IV. Futur of the Curicuriari catchment? Incision faster than podzolization

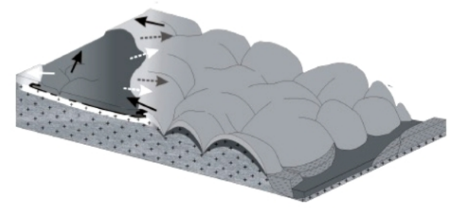

Podzolization faster than incision

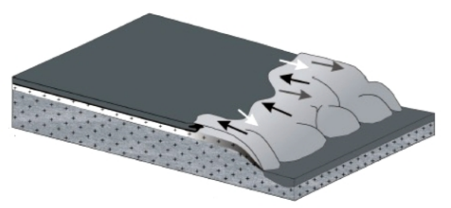


CA Depth $(\mathrm{cm})$ Profile section

\begin{tabular}{|c|c|c|c|c|c|c|c|}
\hline A11 & $0-22$ & Ferrasol & $\begin{array}{r}\text { Dark brown } \\
(7.5 Y R 3 / 4)\end{array}$ & $\begin{array}{l}\text { Sandy clay loam } \\
\text { with coarse sand }\end{array}$ & Granular & $\begin{array}{l}\text { Highly } \\
\text { porous }\end{array}$ & / \\
\hline A12 & $22-41$ & Ferrasol & $\begin{array}{l}\text { Strong brown } \\
(7.5 Y R 4 / 6)\end{array}$ & $\begin{array}{l}\text { Sandy clays with } \\
\text { fine and coarse sand }\end{array}$ & Granular to blocky & Porous & / \\
\hline$B(r)$ & $41-205$ & Ferrasol & $\begin{array}{c}\text { Brown } \\
(5 Y R 5 / 8)\end{array}$ & $\begin{array}{l}\text { Sandy clay with } \\
\text { fine and coarse sand }\end{array}$ & $\begin{array}{c}\text { Blocky with } \\
\text { numerous micropeds }\end{array}$ & Porous & $\begin{array}{l}\text { CA } 84^{*} \\
\text { CA } 117 \\
\text { CA } 155 \\
\text { CA } 200^{*}\end{array}$ \\
\hline$B C(r)$ & $205-345$ & Saprolite & $\begin{array}{c}\text { Red } \\
\text { (2.5YR to } 10 R 4 / 6)\end{array}$ & $\begin{array}{l}\text { Sandy clay loam } \\
\text { with coarse sands }\end{array}$ & $\begin{array}{l}\text { Massive to blocky } \\
\text { with micropeds }\end{array}$ & Porous & $\begin{array}{l}\text { CA } 240 \\
\text { CA } 280\end{array}$ \\
\hline$B C(r)$ & $345-475$ & Saprolite & $\begin{array}{c}\text { Red } \\
(10 R 4 / 6)\end{array}$ & $\begin{array}{l}\text { Sandy clay loam } \\
\text { with coarse sands }\end{array}$ & Massive & Porous & $\begin{array}{l}\text { CA } 360 \\
\text { CA } 380 \\
\text { CA } 400 \\
\text { CA } 440^{*}\end{array}$ \\
\hline $\mathrm{C} 3$ & 475-? & Saprolite & Heterogeneous & $\begin{array}{c}\text { Weathered rock horizon with } \\
\text { numerous relics of feldspatic and } \\
\text { mafic minerals with small amount } \\
\text { of clay }\end{array}$ & / & $\begin{array}{c}\text { No } \\
\text { porosity }\end{array}$ & $\begin{array}{l}\text { CA } 480^{*} \\
\text { CA } 485\end{array}$ \\
\hline
\end{tabular}

\section{CO2 Depth $(\mathrm{cm})$ Profile section}

Color

Texture

Structure

Loamy sand

Olive brown

(2.5YR 4/3) with coarse

Light olive brown

(2.5YR 5/4)

Sandy loam

with fine to coarse sands

Granular

Sandy clay loam

Acrisol

Yellowish brown

(10YR 6/6)

with fine and coarse sand

Sandy clay loam

with fine and coarse sand

(7.5YR 6/6)

Acrisol

Blocky with

micropeds

$\mathrm{B}(\mathrm{r})$
$\mathrm{BC}$
$(\mathrm{r}-\mathrm{y})$

Mottled:

$\mathrm{BC}$

$(\mathrm{r}-\mathrm{y})$

215-365

Saprolite

Reddish yellow (2.5-5 YR 6/6)

Bownish yellow (10YR 6/8) with fine and coarse sands White

\section{Mottled:}

White

Brownish yellow (1YR 6/8)

Reddish yellow (2.5-5YR 6/6)

Sandy clay loam

Sandy clay loam

with fine and coarse sands

Porosity Samples

Porous

Weakly

porous

CO2 25

$\mathrm{CO} 245^{*}$

$\mathrm{CO} 255$

CO2 87

CO2 200*

Porous

$\begin{array}{ll} & \text { No } \\ \text { Massive } & \text { porosity }\end{array}$

CO2 240

CO2 280*

$\mathrm{CO} 2320$

CO2 370

Weathered primary

Massive

No

CO2 405

minerals can be observed 


\begin{tabular}{|c|c|c|c|c|c|c|c|c|c|c|}
\hline Name & Group & $\begin{array}{c}\text { Center-A } \\
\text { Content } \\
\text { (A.U.) } \\
\end{array}$ & $\mathrm{U}(\mathrm{ppm})$ & Th (ppm) & K (\%) & $\begin{array}{c}\% \text { U } \\
\text { matrice }\end{array}$ & $\begin{array}{c}\text { DR } \\
\text { (Gy/ka) }\end{array}$ & $\begin{array}{c}\text { DR } \\
\text { corrected } \\
\text { (Gy/ka) } \\
\end{array}$ & Paleodose (kGy) & Age (Ma) \\
\hline CA 84 & CA1 & 3.67 & 5 & 18.2 & 0.0664 & 48.26 & 29.95 & 17.88 & $27.59+/-8.8$ & $1.54_{+/-0.50}$ \\
\hline CA 117 & CA1 & 3.63 & 4.2 & 20.3 & 0.0332 & 48.26 & 29.18 & 18.18 & 27.19 & 1.50 \\
\hline CA 155 & CA1 & 3.73 & 4.8 & 19.2 & 0.0083 & 34.42 & 30.09 & 16.77 & 28.17 & 1.68 \\
\hline CA 200 & CA2 & 2.76 & 4.6 & 20 & 0.0332 & 34.42 & 30.15 & 17.10 & $18.05+/-4.03$ & $1.05_{+/-0.25}$ \\
\hline CA 240 & CA1 & 1.94 & 8.4 & 23.3 & 0.0581 & 34.42 & 44.39 & 22.87 & 12.69 & 0.55 \\
\hline CA 280 & CA1 & 3.15 & 9.4 & 26.6 & 0.0913 & 34.42 & 50.12 & 25.94 & 22.64 & 0.87 \\
\hline CA 360 & CA3 & 2.33 & 14.3 & 27.8 & 0.0913 & 34.42 & 65.98 & 31.41 & 6.63 & 0.21 \\
\hline CA 380 & CA 3 & 7.50 & NA & NA & NA & 34.42 & NA & NA & 17.13 & NA \\
\hline CA 400 & CA3 & 5.58 & 11.7 & 30.2 & 0.0664 & 34.42 & 59.99 & 30.41 & 16.77 & 0.55 \\
\hline CA 440 & CA3 & 5.31 & 15.4 & 29.7 & 0.0996 & 34.42 & 70.87 & 33.67 & $15.88+/-2.56$ & $0.47_{+/-0.08}$ \\
\hline CA 480 & CA4 & 0.24 & 6.2 & 21.6 & 1.9173 & 34.42 & 38.24 & 21.23 & $1.21+/-0.17$ & Quaternary \\
\hline CA 485 & CA 1 & 5.31 & NA & NA & NA & 34.42 & NA & NA & 11.8 & NA \\
\hline
\end{tabular}




\begin{tabular}{|c|c|c|c|c|c|c|c|c|c|c|}
\hline Name & Group & $\begin{array}{c}\text { Center-A } \\
\text { Content } \\
\text { (A.U.) }\end{array}$ & U (ppm) & Th (ppm) & K (\%) & $\begin{array}{c}\% \text { U } \\
\text { matrice }\end{array}$ & DR (Gy/ka) & $\begin{array}{c}\text { DR } \\
\text { corrected } \\
\text { (Gy/ka) }\end{array}$ & Paleodose (kGy) & Age (Ma) \\
\hline $\mathrm{CO} 225$ & $\mathrm{C} 1$ & 21.23 & 4.3 & 41.65 & 0 & 55.8 & 46.97 & 35.91 & 46.736 & 1.302 \\
\hline CO2 45 & $\mathrm{C} 1$ & 17.76 & 4.03 & 39.9 & 0 & 55.8 & 44.44 & 34.05 & $35.11+/-11.34$ & $1.031+/-0.34$ \\
\hline CO2 55 & $\mathrm{C} 2$ & 4.64 & 3.6 & 14.3 & 0.0083 & 55.8 & 22.49 & 15.55 & 39.12 & 2.515 \\
\hline CO2 87 & $\mathrm{C} 1$ & 20.57 & 3.76 & 44 & 0 & 55.8 & 46.93 & 36.49 & 44.28 & 1.213 \\
\hline CO2 200 & $\mathrm{C} 2$ & 2.92 & 3 & 13 & 0.0166 & 55.8 & 19.62 & 13.72 & $23.92+/-4,33$ & $1.743+/-0.34$ \\
\hline CO2 240 & C3 & 0 & 3 & 13.3 & 0.0415 & 28.83 & 19.89 & 13.09 & Negligible & Quaternary \\
\hline CO2 280 & C3 & 8.11 & 3 & 15.7 & 0.0083 & 28.83 & 21.79 & 14.90 & $68.05_{+/-15,99}$ & $4.568+/-1.12$ \\
\hline CO2 320 & C4 & 14.05 & 2.6 & 20.5 & 0.0166 & 28.83 & 24.46 & 18.18 & 108.73 & 5.982 \\
\hline CO2 370 & C4 & 9.55 & 1.8 & 23 & 0.0664 & 28.83 & 24.1 & 19.35 & 69.74 & 3.605 \\
\hline CO2 405 & C4 & 10.42 & NA & NA & NA & 28.83 & NA & NA & 76.95 & NA \\
\hline CO2 410 & C4 & 10.4 & 0.5 & 24.4 & 0.0332 & 28.83 & 21.24 & 19.12 & 76.735 & 4.013 \\
\hline CO2 450 & $\mathrm{C} 4$ & 13.13 & 2.7 & 20.7 & 0.0332 & 28.83 & 24.94 & 18.44 & $100.92+/-24,2$ & $5.473+/-1.36$ \\
\hline
\end{tabular}


Sample

${ }^{238} \mathrm{U} \mathrm{dpm} / \mathrm{g}$

$4.05+/-0.13 \quad 4.0104+/-0.04$

$2.379+/ 0.08$

$2.791+/-0.028$

1.173

$2.87535+/-0.158$

4.

$4.2054+/-0.028$ 
Declaration of competing interest

The authors declare that they have no known competing financial interests or personal relationships that could have appeared to influence the work reported in this paper. 


\section{SI 1:}
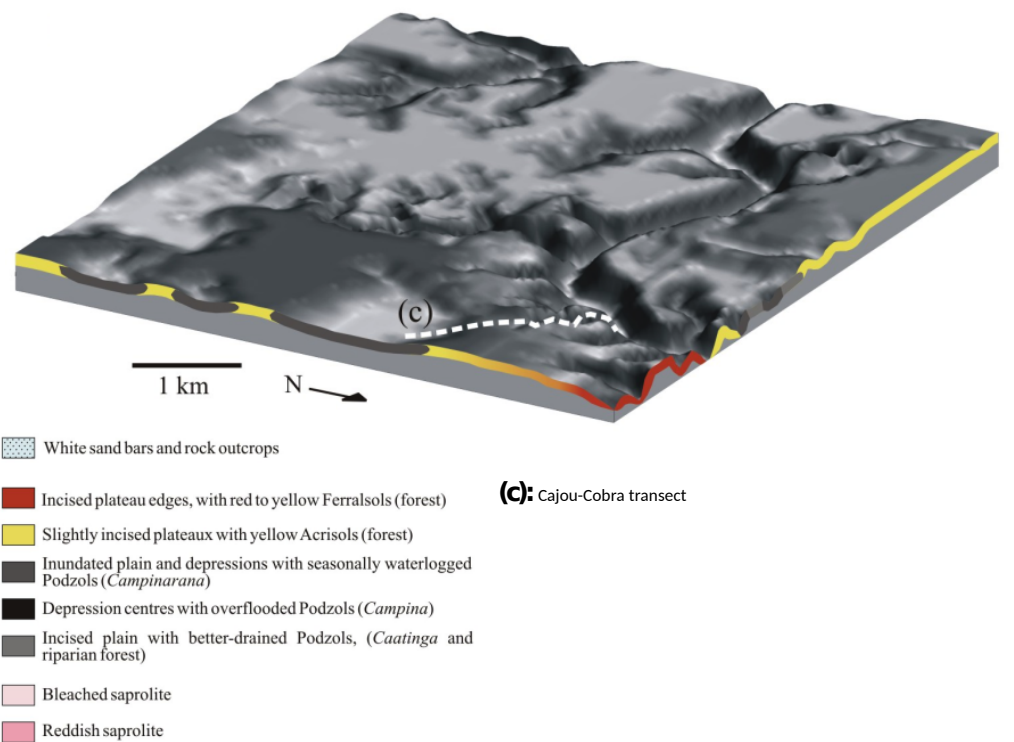

(c): Cajou-Cobra transect

d




\section{SI 2:}

\section{Age (Ma)}

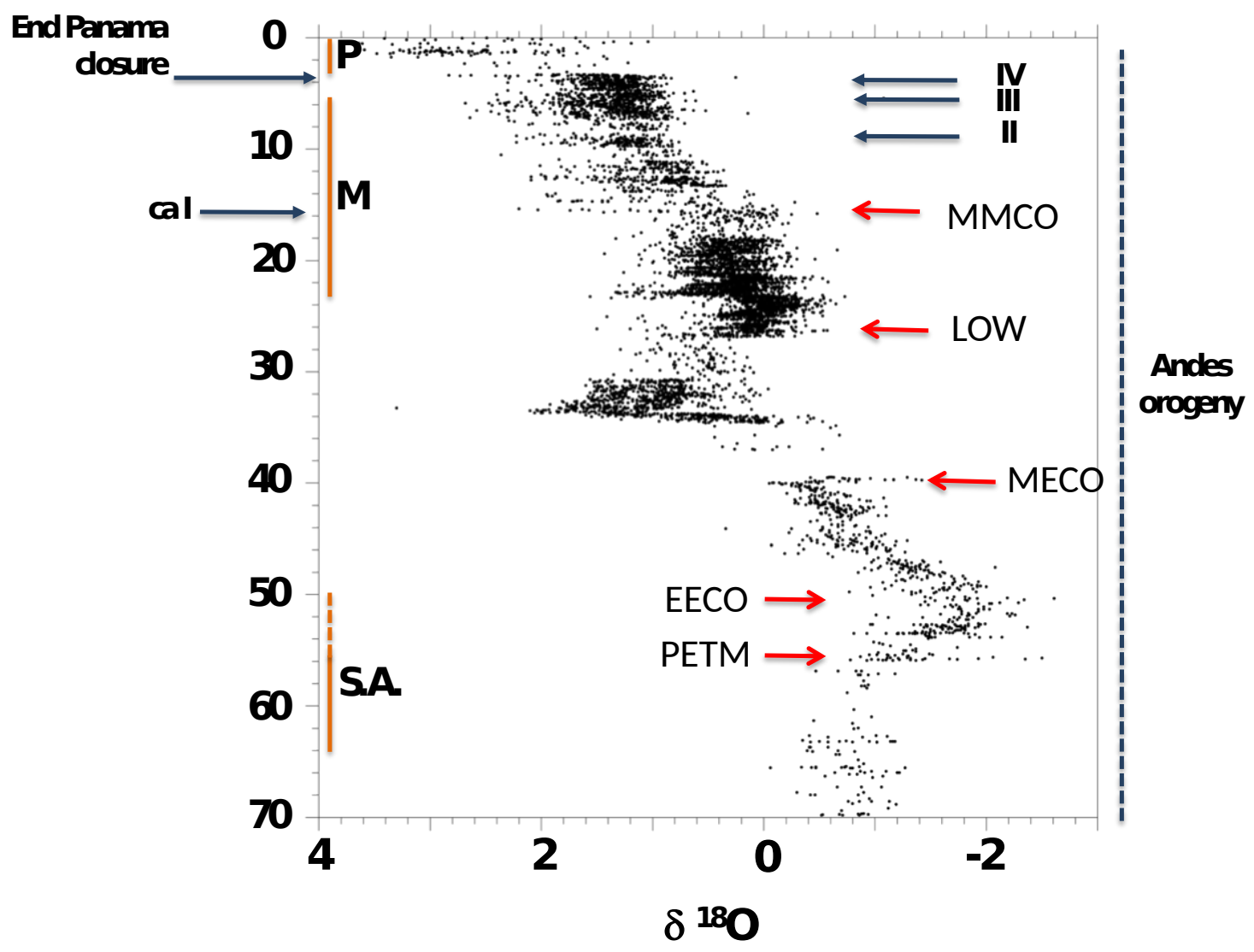

SI2: Delta ${ }^{18} \mathrm{O}$ curve from all oceans from Cramer (2009), the main warming peak and geodynamics events that have affected Amazonia are reported. With: PETM: Paleocene/Eocene Temperature Maximum, EECO: Early Eocène Climatic Optimum, MECO: Mid Eocene Climatic Optimum, LOW: Late Oligocene Warming, MMCO: Mid Miocène Climatic Optimum. The major late tertiary phases of Andean uplifts are reported as ca I: Quechua I; II: Quechua II, III: Quechua III and IV: Pliocene uplift. 
SI 3:

A

\begin{tabular}{|c|c|c|c|c|c|c|c|c|}
\hline Name & $\mathrm{SO}_{2}(\%)$ & $\mathbf{A l}_{2} \mathbf{O}_{3}(\%)$ & $\mathrm{Fe}_{2} \mathrm{O}_{3}(\%)$ & $T \mathrm{O}_{2}(\%)$ & $Z r(p p m)$ & SI/Zr & $A \mid Z r$ & $\mathrm{Fe} / \mathrm{Zr}$ \\
\hline CA4 & 68.92 & 9.58 & 4.72 & 1.105 & 1297 & 0.0531 & 0.0074 & 0.0036 \\
\hline CA 8 & 78.8 & 8.7 & 4.39 & 1.015 & 1006 & 0.0783 & 0.0086 & 0.0044 \\
\hline CA 15 & 70.4 & 12.91 & 5.69 & 1.491 & 1392 & 0.0506 & 0.0093 & 0.0041 \\
\hline CA 30 & 62.86 & 16.82 & 6.99 & 1.869 & 1431 & 0.0439 & 0.0118 & 0.0049 \\
\hline CA 84 & 64.5 & 16.29 & 6.76 & 1.832 & 1554 & 0.0415 & 0.0105 & 0.0044 \\
\hline CA 117 & 64.28 & 17.03 & 7.03 & 1.913 & 1562 & 0.0412 & 0.0109 & 0.0045 \\
\hline CA 155 & 64.25 & 17.13 & 6.83 & 1.905 & 1477 & 0.0435 & 0.0116 & 0.0046 \\
\hline$C A 200$ & 63.74 & 17.5 & 7.03 & 1.94 & 1499 & 0.0425 & 0.0117 & 0.0047 \\
\hline CA240 & 54.62 & 22.06 & 8.65 & 2.061 & 1132 & 0.0483 & 0.0195 & 0.0076 \\
\hline$C A 280$ & 58.06 & 18.74 & 9.54 & 2.261 & 1191 & 0.0487 & 0.0157 & 0.0080 \\
\hline CA320 & 51.19 & 21.82 & 11.18 & 2.258 & 1051 & 0.0487 & 0.0208 & 0.0106 \\
\hline CA360 & 45.08 & 25.07 & 11.4 & 2.09 & 904 & 0.0499 & 0.0277 & 0.0126 \\
\hline CA400 & 52.01 & 22.33 & 9.66 & 2.329 & 1016 & 0.0512 & 0.0220 & 0.0095 \\
\hline CA440 & 53.15 & 20.9 & 11.44 & 2.393 & 1078 & 0.0493 & 0.0194 & 0.0106 \\
\hline CA480 & 46.53 & 22.9 & 10.46 & 1.798 & 842 & 0.0553 & 0.0272 & 0.0124 \\
\hline
\end{tabular}


B:

\begin{tabular}{|c|c|c|c|c|c|c|c|c|}
\hline Name & $\mathrm{SO}_{2}(\%)$ & $\mathrm{Al}_{2} \mathrm{O}_{3}(\%)$ & $\mathrm{Fe}_{2} \mathrm{O}_{3}(\%)$ & $T O_{2}(\%)$ & $\operatorname{Zr}(\mathrm{ppm})$ & $S / Z r$ & $\mathbf{A} / \mathbf{Z} \mathbf{r}$ & $\mathrm{Fe} / \mathrm{Zr}$ \\
\hline CO2-7 & 84.92 & 4.46 & 2.02 & 1.011 & 1527 & 0.0556 & 0.0029 & 0.0013 \\
\hline CO2-15 & 82.86 & 5.93 & 2.31 & 1.296 & 1790 & 0.0463 & 0.0033 & 0.0013 \\
\hline CO2-30 & 82.82 & 6.83 & 2.51 & 1.404 & 1717 & 0.0482 & 0.0040 & 0.0015 \\
\hline CO2-55 & 81.34 & 8.33 & 2.82 & 1.582 & 1775 & 0.0458 & 0.0047 & 0.0016 \\
\hline CO2-105 & 80.37 & 9.62 & 2.93 & 1.719 & 1878 & 0.0428 & 0.0051 & 0.0016 \\
\hline CO2-155 & 79.72 & 10.37 & 2.78 & 1.641 & 1882 & 0.0424 & 0.0055 & 0.0015 \\
\hline CO2-200 & 77.05 & 11.66 & 3.63 & 1.478 & 1756 & 0.0439 & 0.0066 & 0.0021 \\
\hline$\infty 02-240$ & 74.81 & 15.24 & 1.47 & 1.257 & 1907 & 0.0392 & 0.0080 & 0.0008 \\
\hline CO2-280 & 72.2 & 15.41 & 3.13 & 1.233 & 895 & 0.0807 & 0.0172 & 0.0035 \\
\hline Co2-320 & 63.15 & 22.71 & 2.07 & 1.676 & 907 & 0.0696 & 0.0250 & 0.0023 \\
\hline co2-370 & 58.69 & 26.99 & 0.98 & 1.838 & 738 & 0.0795 & 0.0366 & 0.0013 \\
\hline$\infty 2-410$ & 60.41 & 25.82 & 0.9 & 1.797 & 806 & 0.0750 & 0.0320 & 0.0011 \\
\hline CO2-435 & 69.97 & 18.4 & 1.04 & 2.473 & 1076 & 0.0650 & 0.0171 & 0.0010 \\
\hline CO2-450 & 61.36 & 25.32 & 0.94 & 1.769 & 789 & 0.0778 & 0.0321 & 0.0012 \\
\hline
\end{tabular}

SI 3: Tables representing the $\mathrm{SiO}_{2}, \mathrm{Al}_{2} \mathrm{O}_{3}, \mathrm{Fe}_{2} \mathrm{O}_{3}, \mathrm{TiO}_{2}$ and $\mathrm{Zr}$ content and $\mathrm{Si} / \mathrm{Zr}, \mathrm{Al} / \mathrm{Zr}$ and $\mathrm{Fe} / \mathrm{Zr}$ calculations for CA (A), CO2 (B). 
SI 4:

A

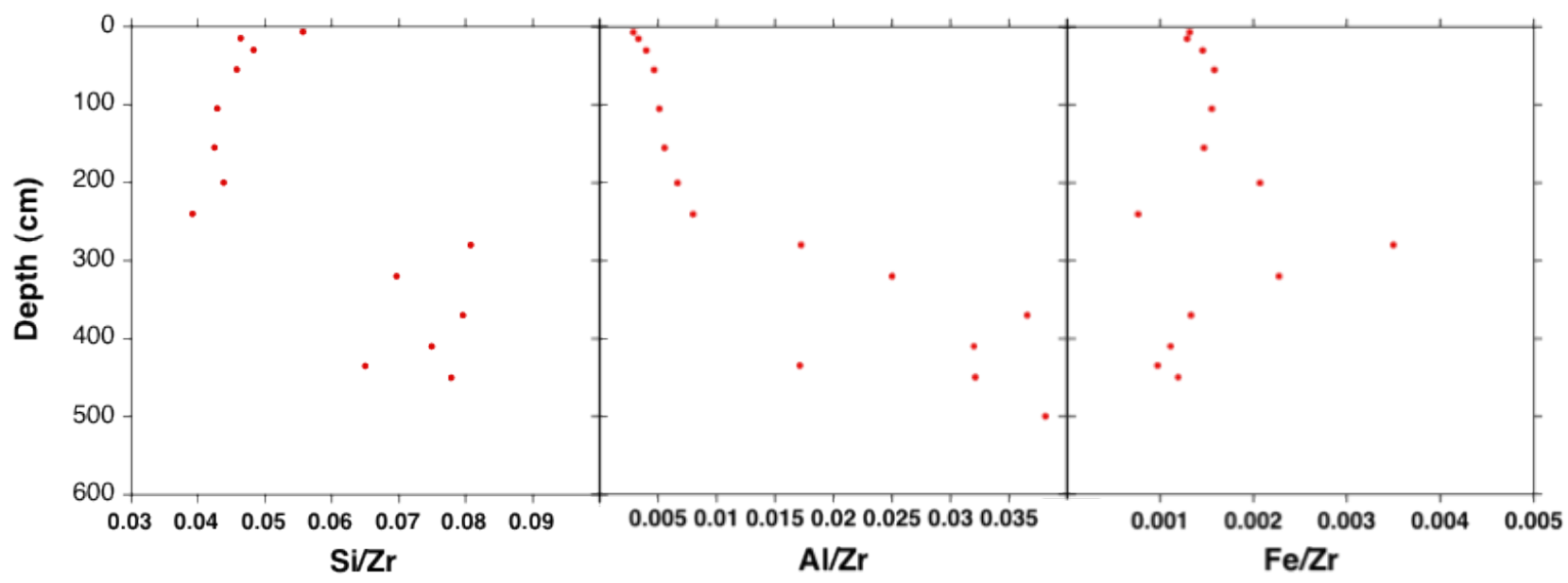

B

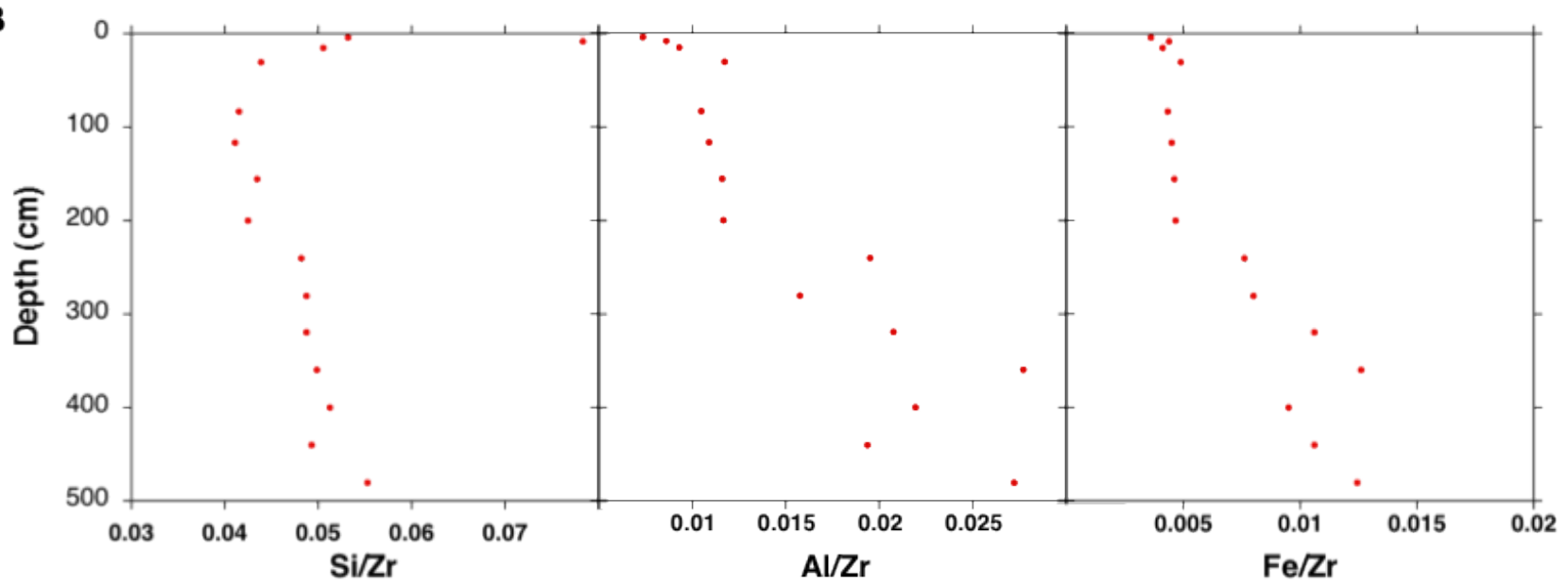

SI 4: $\mathrm{Si}, \mathrm{Al}$ and $\mathrm{Fe}$ content compared to $\mathrm{Zr}$ content evolution within $\mathrm{Ca}(\mathrm{A})$ and $\mathrm{CO} 2(\mathrm{~B})$. 
SI 5:

\begin{tabular}{|c|c|c}
\hline Sample & $\begin{array}{c}\text { Ratio } \\
\text { I KIn/I Gbst }\end{array}$ & $\begin{array}{c}\text { Ratio } \\
\text { I KIn/I Qtz }\end{array}$ \\
\hline CO2 450 & 98,1 & 3,4 \\
\hline CO2 410 & 164,8 & 2,8 \\
\hline CO2 405 & 164,9 & 1,8 \\
\hline CO2 370 & 136,6 & 2,1 \\
\hline CO2 320 & 62,6 & 0,8 \\
\hline CO2 280 & 17,7 & 0,3 \\
\hline CO2 240 & 3,4 & 0,5 \\
\hline CO2 200 & 3,0 & 0,2 \\
\hline CO2 87 & 6,7 & 0,1 \\
\hline CO2 45 & 7,5 & 0,1 \\
\hline CO2 25 & 6,3 & 0,1 \\
\hline Sample & Ratio & Ratio \\
\hline CA 480 & 20,2 & 0,2 \\
\hline CA 440 & 7,3 & 0,7 \\
\hline CA 400 & 5,0 & 0,5 \\
\hline CA 360 & 20,0 & 0,5 \\
\hline CA 280 & 4,7 & 0,8 \\
\hline CA 240 & 4,0 & 0,5 \\
\hline CA 200 & 1,2 & I Gbst/I Qtz \\
\hline CA 155 117 & 1,5 & 0,7 \\
\hline
\end{tabular}

SI 5: Ratios of Integrated area of the diagnostic peaks of 3 main minerals (Kaolinite (Kln); Quartz (Qtz); Gibbsite (Gbst)) observed with the XRD in the Acrisol (Cobra, CO2) and Ferralsol (Cajou, CA) profiles. Note that the present approach only provides a qualitative assesment of the variations of mineral proportions among the samples. 
SI 6:

\begin{tabular}{|c|c|c|c|c|c|}
\hline & $\begin{array}{c}\text { Amplitude } \\
\mathrm{g}=1.881\end{array}$ & $R_{V O^{2}}^{2^{+}} \times 100$ & Amplitude $\mathrm{g}=2$ & $T I_{d i m} \times R_{V O^{2}}^{2^{+}}$ & $I_{R I D}$ \\
\hline DIMEX & 1.9547 & 100 & 12.014 & 12.014 & 0 \\
\hline $\mathrm{CO} 245$ & 0.059 & 3.02 & 18.12 & 0.36 & 17.76 \\
\hline CO2 200 & 0.907 & 46.40 & 8.49 & 5.57 & 2.92 \\
\hline CO2 280 & 1.058 & 54.13 & 14.614 & 6.50 & 8.11 \\
\hline $\mathrm{CO} 2450$ & 0.642 & 32.84 & 17.08 & 3.95 & 13.13 \\
\hline $\mathrm{CO} 225$ & 0.07 & 3.58 & 21.66 & 0.43 & 21.23 \\
\hline $\mathrm{CO} 255$ & 0.555 & 28.39 & 8.048 & 3.41 & 4.64 \\
\hline $\mathrm{CO} 287$ & 0.111 & 5.68 & 21.25 & 0.68 & 20.57 \\
\hline CO2 240 & 2.7 & 138.13 & 16.596 & 16.59 & 0.001 \\
\hline CO2 320 & 0.673 & 34.43 & 18.19 & 4.14 & 14.05 \\
\hline CO2 370 & 0.795 & 40.67 & 14.44 & 4.89 & 9.55 \\
\hline $\mathrm{CO} 2405$ & 0.725 & 37.09 & 14.88 & 4.46 & 10.42 \\
\hline \multirow[t]{2}{*}{$\mathrm{CO} 2410$} & 0.729 & 37.29 & 14.88 & 4.48 & 10.4 \\
\hline & $\begin{array}{c}\text { Amplitude } \\
\mathrm{g}=1.881\end{array}$ & $R_{V O}{ }^{2^{+}} \times 100$ & Amplitude $\mathrm{g}=2$ & $T I_{d i m} \times R_{V O}^{2^{+}}$ & $I_{R I D}$ \\
\hline DIMEX & 1.9547 & 100 & 12.014 & 12.014 & 0 \\
\hline CA 84 & 0.25 & 12.79 & 5.21 & 1.54 & 3.67 \\
\hline CA 200 & 0.36 & 18.42 & 4.971 & 2.21 & 2.76 \\
\hline$C A 440$ & 0.496 & 25.37 & 8.36 & 3.05 & 5.31 \\
\hline CA 480 & 0.19 & 9.72 & 1.41 & 1.17 & 0.24 \\
\hline CA 117 & 0.24 & 12.02 & 5.075 & 1.447 & 3.63 \\
\hline CA 155 & 0.166 & 8.49 & 4.75 & 1.02 & 3.73 \\
\hline CA 240 & 0.71 & 36.32 & 6.3 & 4.36 & 1.94 \\
\hline CA 280 & 0.72 & 36.83 & 7.575 & 4.425 & 3.15 \\
\hline CA 360 & 0.92 & 47.06 & 7.988 & 5.65 & 2.33 \\
\hline CA 380 & 0.36 & 18.42 & 9.708 & 2.21 & 7.495 \\
\hline$C A 400$ & 0.237 & 12.12 & 7.0416 & 1.47 & 5.58 \\
\hline CA 485 & 0.281 & 14.375 & 7.0416 & 1.73 & 5.31 \\
\hline
\end{tabular}

SI 6: Vanadium calculations parameters for $\mathrm{CA}$ and $\mathrm{CO} 2$. The presented intensities are in arbitrary units (A.U.). 
SI 7:

\begin{tabular}{|c|c|c|c|c|c|}
\hline Nom & Group & $\mathbf{I}_{\infty}$ & $\mu$ & $\mathbf{P}$ & FI \\
\hline CA 84 & CA1 & 6.82931 & 0.0227504 & 27.5937 & 0.0176381 \\
\hline CA 200 & $C A 2$ & 5.31906 & 0.0325731 & 18.0472 & 0.0219315 \\
\hline CA 440 & $C A 3$ & 29.9766 & 0.0116196 & 15.8807 & 0.0162449 \\
\hline CA 480 & CA4 & 9.5483 & 0.020617 & 1.2083 & 0.0042056 \\
\hline Nom & Famille & $\mathbf{I}_{\infty}$ & $\mu$ & $\mathbf{P}$ & $\mathrm{FI}$ \\
\hline $\mathrm{CO} 245$ & $C 1$ & 29.3814 & 0.0237984 & 35.1125 & 0.032279 \\
\hline CO2 200 & $C 2$ & 16.4384 & 0.00597831 & 23.9165 & 0.0309003 \\
\hline CO2 280 & C3 & 24.2533 & 0.00417967 & 68.0466 & 0.0326472 \\
\hline CO2 450 & C4 & 25.52039 & 0.004489324 & 100.9248 & 0.03859895 \\
\hline
\end{tabular}

SI 7: Dosimetry curves fitting parameters for artificially irradiated samples from CA and Co2 With $\mathrm{m} 1$ the RID's concentration at saturation, $\mathrm{m} 2$ the efficiency factor, $\mathrm{m} 3$ the natural paleodose and $\mathrm{m} 4$ the linear parameter. 
SI 8:

A

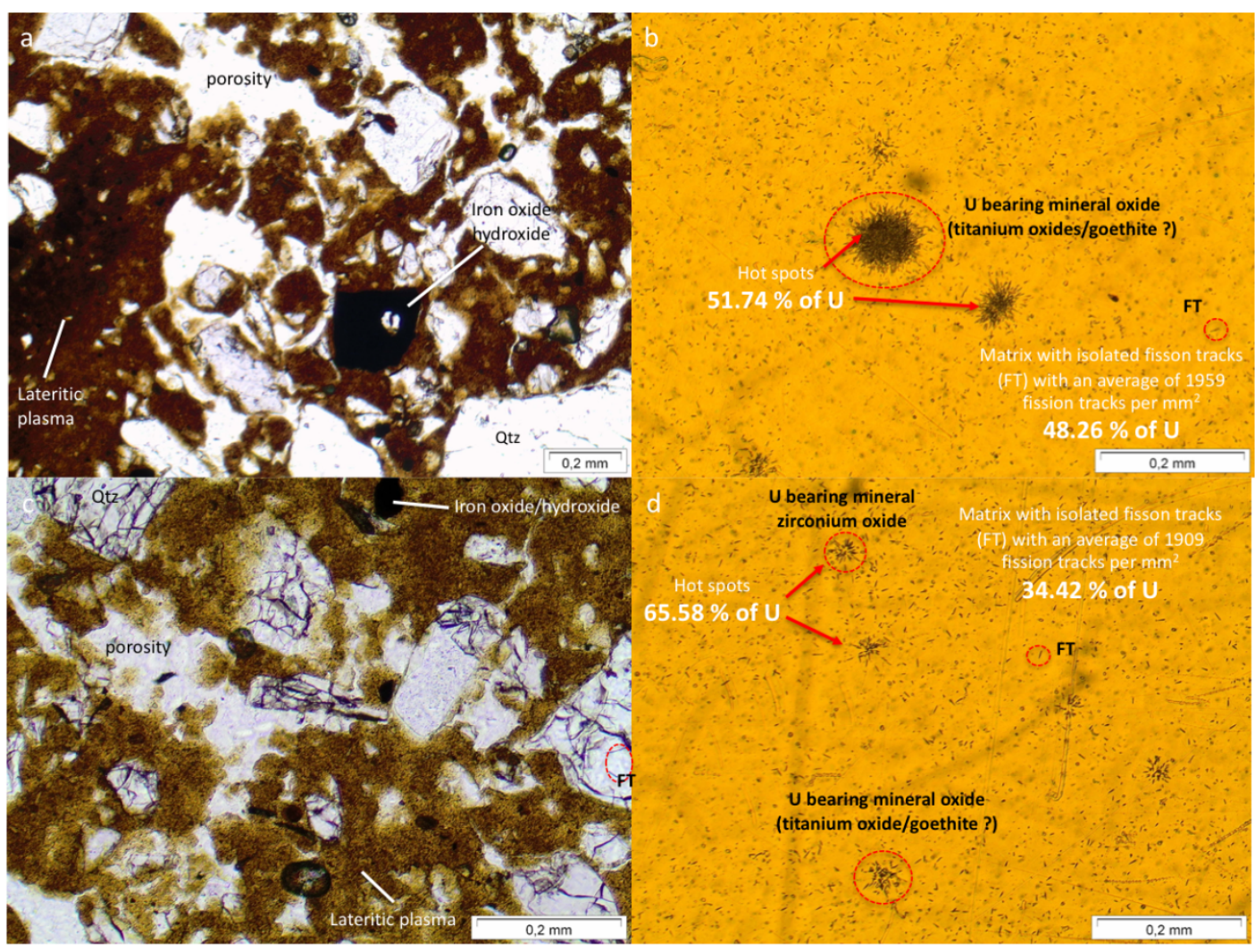

B

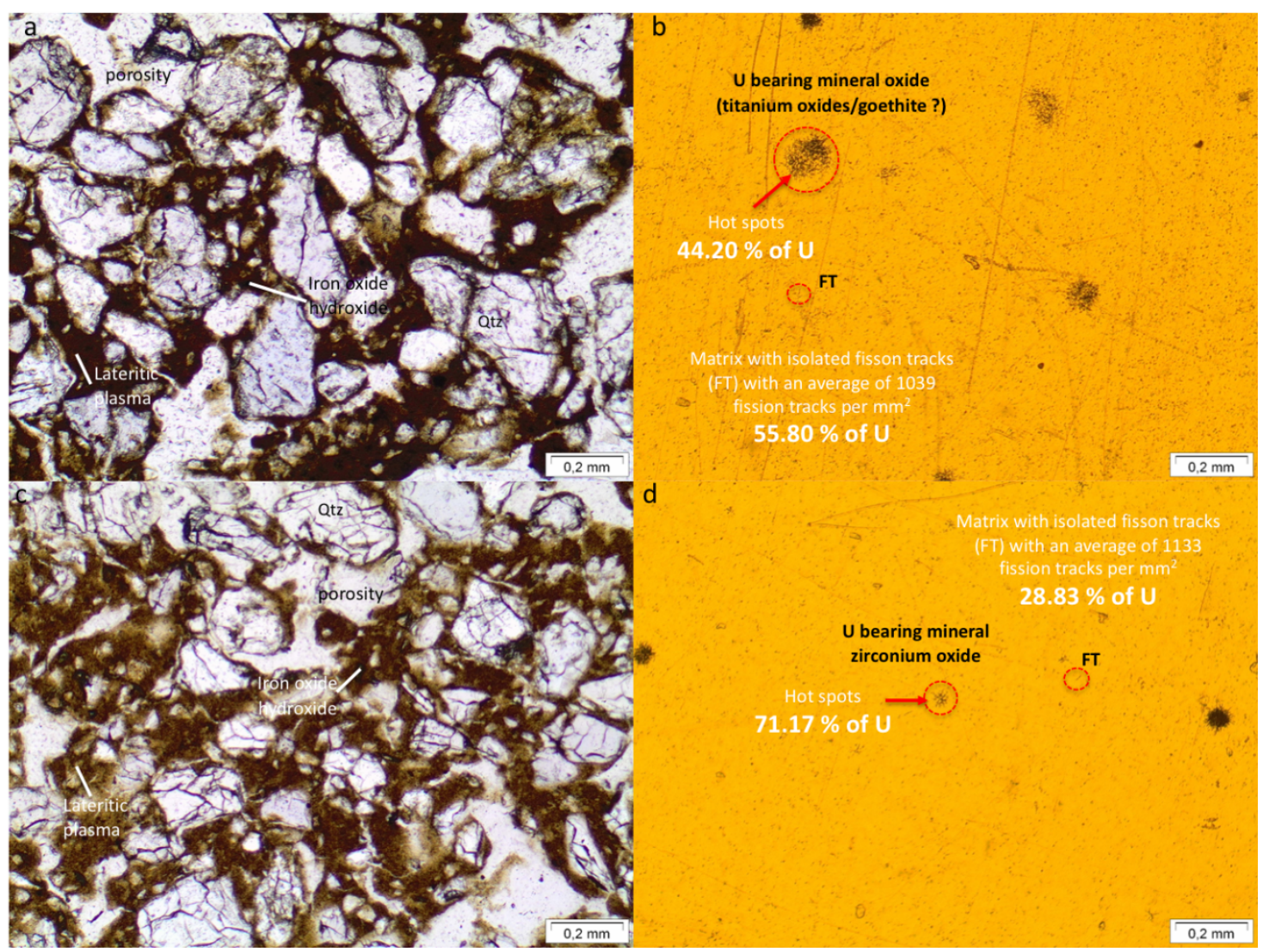


SI 8: A- General petrographic view of the CA samples, CA 84 (a) and CA 155 (c) and the corresponding fission tracks mapping results (b for CA 84 and $\mathrm{d}$ for CA 155). The petrographic organisation of these samples is characterized by a high amount of quartz dispersed with oxides within a lateritic plasma containing kaolinite and iron oxides/hydroxides. B- General petrographic view of the CO2 samples, CO2 87 (a) and CO 3875 (c) and the corresponding fission tracks mapping results ( $\mathrm{b}$ for $\mathrm{CO} 287$ and $\mathrm{d}$ for $\mathrm{CO} 3875$ ). The petrographic organisation of these samples is characterized by a high amount of quartz with a minor content of lateritic plasma and oxides. This is particularly visible for the CO2 87 sample. 